Prepared for the U.S. Department of Energy under Contract DE-AC05-76RL01830

\title{
Perched-Water Evaluation for the Deep Vadose Zone Beneath the B, BX, and BY Tank Farms Area of the Hanford Site
}

\author{
MJ Truex \\ M Oostrom \\ KC Carroll \\ GB Chronister
}

June 2013

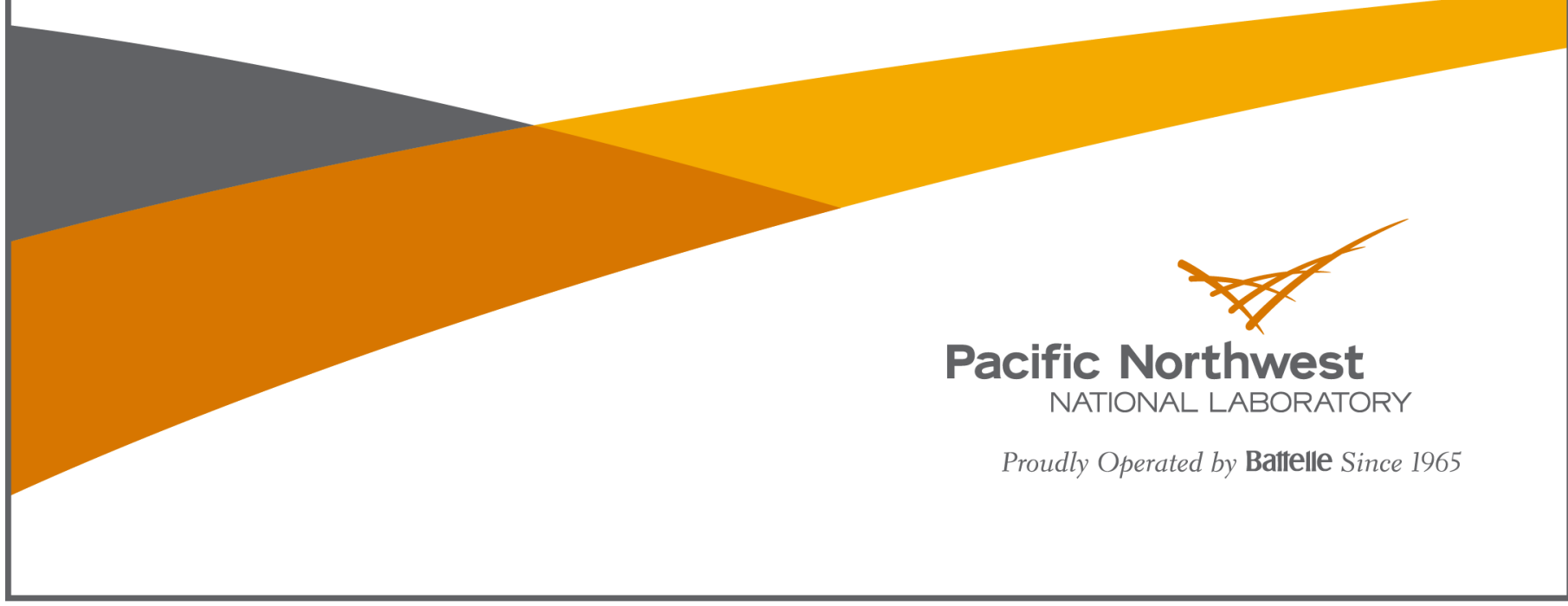




\title{
DISCLAIMER
}

This report was prepared as an account of work sponsored by an agency of the United States Government. Neither the United States Government nor any agency thereof, nor Battelle Memorial Institute, nor any of their employees, makes any warranty, express or implied, or assumes any legal liability or responsibility for the accuracy, completeness, or usefulness of any information, apparatus, product, or process disclosed, or represents that its use would not inf ringe privately owned rights. Reference herein to any specific commercial product, process, or service by trade name, trademark, manufacturer, or otherwise does not necessarily constitute or imply its endorsement, recommendation, or favoring by the United States Government or any agency thereof, or Battelle Memorial Institute. The views and opinions of authors expressed herein do not necessarily state or reflect those of the United States Government or any agency thereof.

\author{
PACIFIC NORTHWEST NATIONAL LABORATORY \\ operated by \\ BATTELLE \\ for the \\ UNITED STATES DEPARTMENT OF ENERGY \\ under Contract DE-AC05-76RL01830
}

Printed in the United States of America
Available to DOE and DOE contractors from the
Office of Scientific and Technical Information
P.O. Box 62, Oak Ridge, TN 37831-0062;
ph: (865) 576-8401
fax: $(865) 576-5728$
email: reports@adonis.osti.gov

Available to the public from the National Technical Information Service

5301 Shawnee Rd., Alexandria, VA 22312

ph: (800) 553-NTIS (6847)

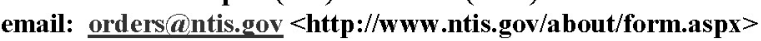

Online ordering: http://www.ntis.gov

This document was printed on recycled paper. 
PNNL-22499

RPT-DVZ-AFRI-013

\title{
Perched-Water Evaluation for the Deep Vadose Zone Beneath the B, BX, and BY Tank Farms Area of the Hanford Site
}

\author{
MJ Truex \\ M Oostrom \\ KC Carroll \\ GB Chronister $^{1}$
}

June 2013

Prepared for

the U.S. Department of Energy

under Contract DE-AC05-76RL01830

Pacific Northwest National Laboratory

Richland, Washington 99352

\footnotetext{
${ }^{1}$ CH2M HILL Plateau Remediation Company, Richland, Washington.
} 



\section{Executive Summary}

Perched-water conditions have been observed in the vadose zone above a fine-grained zone that is located a few meters above the water table within the B, BX, and BY Tank Farms area. The perched water contains elevated concentrations of uranium and technetium-99. This perched-water zone is important to consider in evaluating the future flux of contaminated water into the groundwater. The study described in this report was conducted to examine the perched-water conditions and quantitatively evaluate 1) factors that control perching behavior, 2) contaminant flux toward groundwater, and 3) associated groundwater impact.

A perched-water zone in the subsurface is defined as a saturated zone that is above or not directly connected to the regional water table. Perching phenomena may occur in a permeable layer overlaying a relatively impermeable layer. A perched-water zone develops when saturated conditions above a lowpermeability layer are needed to move infiltrating water vertically through this layer. Water infiltrating through the vadose zone encounters a resistance at a low-permeability layer and must build up pressure, in the form of a perched-water head, to conduct water through the layer. Over time, the perched-water system may reach an equilibrium condition where the rate of infiltration equals the rate of water moving out of the perched-water zone and deeper toward the groundwater. Perched water can occur under natural recharge conditions and the perched-water height would remain essentially constant over time if the infiltration rate from the surface remained constant. Transient perched-water zones can also occur when infiltration at the surface is increased due to surface disturbance (e.g., removal of vegetation or construction activities) or due to a discharge of water (or aqueous waste). When the overall system recharge rate is increased, perched water may form and then persist until recharge is reduced or water discharge is terminated and the impact of excess water in the vadose zone dissipates. At the B, BX, and BY Tank Farms area, both of these factors may have contributed to forming the current perched water.

The presence of perched water enables use of a pumping system for removal of contaminant mass from the subsurface to decrease the total contaminant mass that would eventually move into the groundwater. Under most of the tested scenarios, the perched water is a transient condition, although continuation of current disturbed-surface recharge conditions for the B, BX, and BY Tank Farms area may maintain the perched-water zone to some extent even as the impacts of historical waste and water discharges dissipate. For transient perched-water conditions, especially when coupled with a decreased recharge rate (and/or dissipation of previous waste and water discharges), declining perched-water height will render removal of perched water more difficult with time. As such, near-term actions to remove perched water will be more effective. Removal of perched water by pumping would hasten the transition to conditions in which the flux of water (and associated contaminants) through the vadose zone to the groundwater is equal to the recharge rate. Reducing the recharge rate would further decrease the flux of water (and associated contaminants) to the groundwater, thereby impacting the long-term rate of contaminant movement to the groundwater. Reduction of recharge is also important to consider because contaminants are present in other parts of the vadose zone, not only within the current perched water. Thus, a coupled effort of perched-water removal and recharge rate reduction would cause the most significant decrease in contaminant flux to the groundwater. In addition, other methods to decrease contaminant flux through the vadose zone (e.g., in situ treatment) could be combined with these approaches to further decrease impact to groundwater, if needed. 
Steady-state scoping calculations were used to evaluate a wide range of recharge and perching-layer hydraulic conductivity conditions with respect to creating perched water. These results helped bound the range of conditions that are consistent with the observed perched water. Numerical simulations provided both steady-state and transient system estimates of water and contaminant behavior and were used to further refine the range of conditions consistent with current observations of perched water height. In addition, the simulations provided estimates of future water and contaminant flux to groundwater for those conditions. The modeling analyses were conducted and compared to the currently available perched-water data, which represent a relatively short timeframe, to bound the range of future perchedwater behavior. Thus, continued observation of the perched-water height over time and the response to continued pumping operations will be useful to refine and improve the estimates of perched-water conditions and associated predictions of flux to groundwater.

A limited number of perched-system configurations are consistent with water flow physics within the vadose zone and the range of historical recharge and waste discharge conditions. For simulation results to be consistent with the estimated recent and current recharge for disturbed surface conditions (on the order of $6 \mathrm{~cm} / \mathrm{yr})$ and the observed relatively stable perched-water height during a year of pumping $(\sim 3.36 \mathrm{~m})$, the perching-layer hydraulic conductivity is likely to be in the vicinity of $1 \times 10^{-7} \mathrm{~cm} / \mathrm{s}$. Under these conditions, the perched water height would be expected to slowly decline over a period of about 20 years to reach a steady-state condition where perched water is still present but at a height $(\sim 0.8 \mathrm{~m})$ less than that observed today. Water flux from the perched water to the groundwater during the decline in the perched water height would be in the range of $10 \mathrm{~cm} / \mathrm{yr}$ (current) and decline to the steady-state value of $6 \mathrm{~cm} / \mathrm{yr}$. If the recharge rate is decreased from $6 \mathrm{~cm} / \mathrm{yr}$ to $0.35 \mathrm{~cm} / \mathrm{yr}$ (e.g., through installation of a surface barrier or other means), the perched water table would decline and reach unsaturated conditions. This decline could occur over a period of up to about 10 years for a perching-layer hydraulic conductivity of $1 \times 10^{-7} \mathrm{~cm} / \mathrm{s}$. During this time, water flux from the perched water to the groundwater would decline from about $10 \mathrm{~cm} / \mathrm{yr}$ to $0.35 \mathrm{~cm} / \mathrm{yr}$ and contaminant flux to the groundwater would be reduced and delayed significantly. Removal of perched water via pumping would hasten the timeframe for the above changes and decrease the total contaminant mass that will eventually move into the groundwater. Additional scenarios with combinations of perching-layer hydraulic conductivity and recharge rate were also evaluated with detailed results presented in the report.

This study was intended to provide a quantitative context for interpreting the observed perched-water system and ramifications for groundwater impact based on a hydraulic analysis of the vadose zone system. The concentration profile and extent of the groundwater plume produced by contaminant flux from the vadose zone is related to three-dimensional aspects of the subsurface system. Use of a coupled analysis for the vadose zone source and the groundwater transport system could be applied to evaluate the nature and extent of the groundwater plume over time and could incorporate aspects of the current study in defining the vadose zone source term. 


\section{Acknowledgments}

This document was prepared by the Deep Vadose Zone-Applied Field Research Initiative at Pacific Northwest National Laboratory. Funding for this work was provided by the U.S. Department of Energy, Richland Operations Office. The Pacific Northwest National Laboratory is operated by Battelle Memorial Institute for the U.S. Department of Energy under Contract DE-AC05-76RL01830. 



\section{Acronyms and Abbreviations}

$\begin{array}{ll}\text { bgs } & \text { below ground surface } \\ \mathrm{CCU} & \text { Cold Creek Unit } \\ \mathrm{cm} & \text { centimeter(s) } \\ \mathrm{DOE} & \text { U.S. Department of Energy } \\ \mathrm{ft} & \text { foot/feet } \\ \mathrm{INEEL} & \text { Idaho National Engineering and Environmental Laboratory } \\ \mathrm{kg} & \text { kilogram(s) } \\ \mathrm{L} & \text { liter(s) } \\ \text { LANL } & \text { Los Alamos National Laboratory } \\ \mathrm{m} & \text { meter(s) } \\ \mathrm{m}^{2} & \text { square meter(s) } \\ \mathrm{m}^{3} & \text { cubic meter(s) } \\ \text { STOMP } & \text { Subsurface Transport Over Multiple Phases } \\ \text { Tc } & \text { technetium-99 } \\ \mathrm{U} & \text { uranium } \\ \mathrm{yr} & \text { year(s) }\end{array}$





\section{Contents}

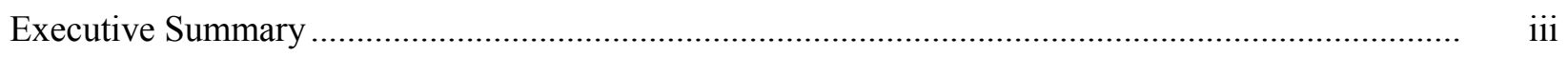

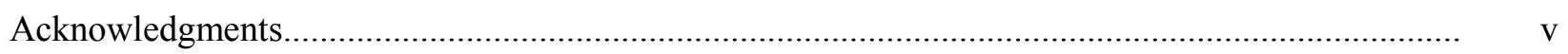

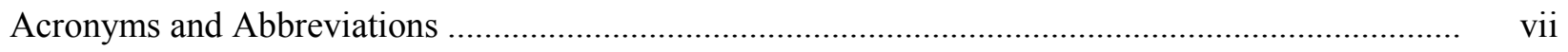

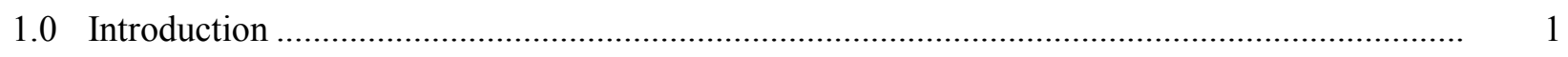

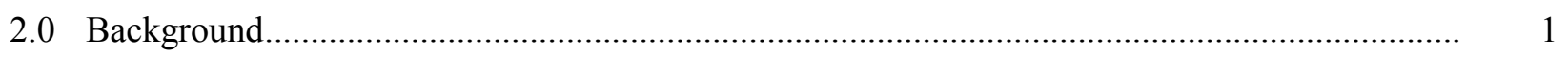

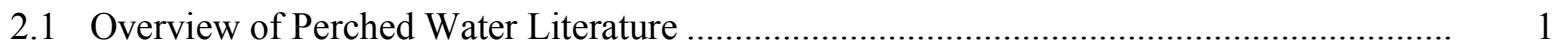

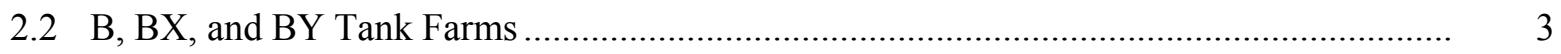

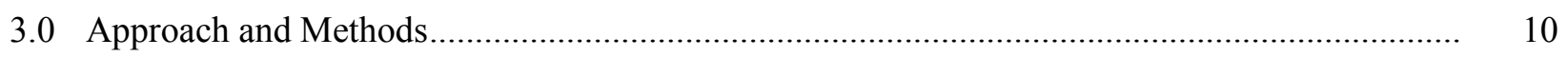

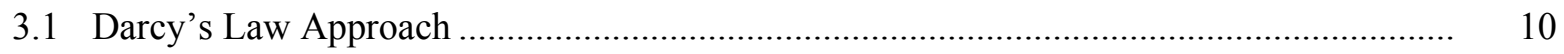

3.2 Numerical Modeling Approach...................................................................................... 10

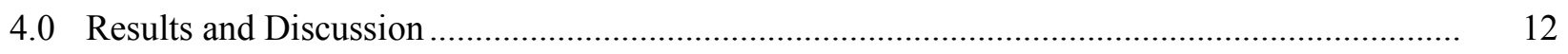

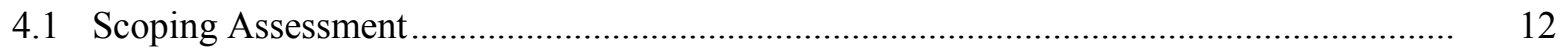

4.2 Numerical Simulation Assessment.............................................................................. 14

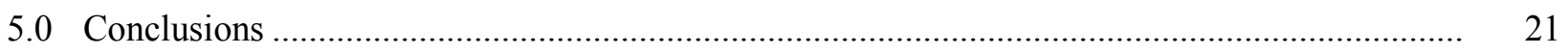

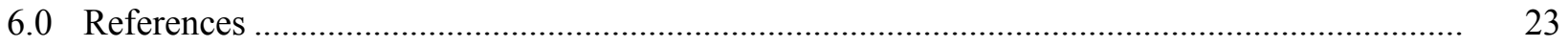

\section{Figures}

1 Site map indicating waste sites and well locations for the B, BX, and BY Tank Farms area ...... 4

2 Generalized stratigraphy for the B-Complex area from Serne et al. (2010), cross

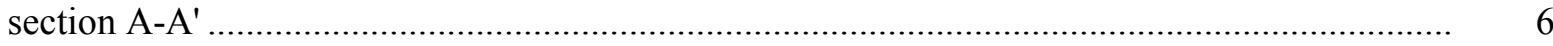

3 Generalized conceptual stratigraphic model of the perched-water zone near wells

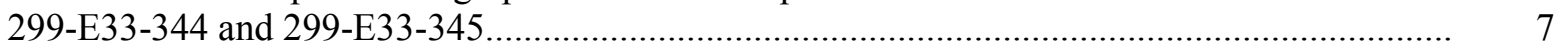

4 Observed water saturation with depth at adjacent wells 299-E33-344 and 299-E33-345 .......... 7

$5 \quad$ Cold Creek Unit silt thickness contour map .......................................................................... 8

$6 \quad$ Water volume and extraction rates from the perched-water zone via well 299-E33-344........... 9

7 Perched-water height above the pressure transducer in well 299-E33-344 ............................. 9

8 Perched-water height as a function of recharge rate and millions of liters discharged for selected perching-layer-saturated hydraulic conductivity values

9 Perched-water height as a function of perching-layer-saturated hydraulic conductivity reduction from the base case value of $1.22 \times 10^{-5} \mathrm{~cm} / \mathrm{s}$ and the recharge rate.

10 Predicted steady-state water saturation distribution with depth for selected perching-layersaturated hydraulic conductivity values and a recharge rate of $0.35 \mathrm{~cm} / \mathrm{yr}$ and $6 \mathrm{~cm} / \mathrm{yr}$......

11 Simulated perched-water height starting from an imposed initial perched-water height of $3.36 \mathrm{~m}$ for selected perching-layer-saturated hydraulic conductivity values and a recharge rate of $0.35 \mathrm{~cm} / \mathrm{yr}$ and $6 \mathrm{~cm} / \mathrm{yr}$. 
12 Simulated transient water flux out the bottom of the perching layer and to groundwater with an imposed initial perched-water height of $3.36 \mathrm{~m}$ for selected perching-layersaturated hydraulic conductivity values and a recharge rate of $0.35 \mathrm{~cm} / \mathrm{yr}$ and $6 \mathrm{~cm} / \mathrm{yr}$

13 Simulated transient contaminant flux out the bottom of the perching layer and to groundwater with an imposed initial perched-water height of $3.36 \mathrm{~m}$ for selected perching-layer-saturated hydraulic conductivity values and a recharge rate of $0.35 \mathrm{~cm} / \mathrm{yr}$ and $6 \mathrm{~cm} / \mathrm{yr}$

14 Simulated transient contaminant flux out the bottom of the perching layer and to groundwater with an imposed initial perched-water height of $3.36 \mathrm{~m}$ and at the steady-state perched-water height for a perching-layer-saturated hydraulic conductivity of $1.22 \times 10^{-7} \mathrm{~cm} / \mathrm{s}$ and a recharge rate of $6 \mathrm{~cm} / \mathrm{yr}$

15 Simulated transient contaminant flux out the bottom of the perching layer and to groundwater with an imposed initial perched-water height of $3.36 \mathrm{~m}$, a perching-layersaturated hydraulic conductivity of $1.22 \times 10^{-7} \mathrm{~cm} / \mathrm{s}$, and a recharge rate of $6 \mathrm{~cm} / \mathrm{yr}$

\section{Table}

1 Overview of model values for sediment layer thickness, hydraulic property, longitudinal dispersivity, and uranium partition coefficient 


\subsection{Introduction}

At the U.S. Department of Energy Hanford Site, uranium (U) and other waste materials were discharged to the subsurface at the B, BX, and BY Tank Farms area through engineered waste sites from 1955 through the mid-1970s. Additional waste was released through waste storage tank leaks (e.g., tank BX-102). As a result of previous tank leaks and waste site discharges, the vadose zone beneath the B-Complex has become contaminated. Some of the contamination has begun to migrate into the groundwater, creating groundwater contamination plumes. Perched-water conditions have been observed in the vadose zone above a fine-grained zone that is located a few meters above the water table within the B, BX, and BY Tank Farms area. The perched water contains elevated concentrations of $U$ and technetium-99 (Tc).

The conceptual model for the B, BX, and BY Tank Farms area and associated contamination has been described by Lindenmeier et al. (2008) and Serne et al. (2008, 2010). In this area, the Cold Creek Unit (CCU) low-permeability layer is structured such that a perched-water zone has formed, intercepting movement of contaminated water through the vadose zone. This perched-water zone is important to consider in evaluating the future flux of contaminated water into the groundwater. Key elements of remediation decisions supported through estimating the future contaminated water flux at this controlling feature are 1) determining the impact of perched water on the vertical contaminated water flux toward the groundwater and 2) providing a basis from which to predict contaminant concentrations in groundwater over time as a function of the perched-water conditions.

The study described in this report was conducted to examine the perched-water conditions and quantitatively evaluate 1) factors that control perching behavior, 2) contaminant flux toward groundwater, and 3) associated groundwater impact. The study also evaluated how measurements of transient decline in perched-water level can be used to help characterize the perched-water system and estimate flux to groundwater. The study followed the remediation assessment framework proposed by Truex and Carroll (2013).

\subsection{Background}

\subsection{Overview of Perched Water Literature}

One of the relatively new areas in vadose zone hydrologic research is the field of perched water studies. The area has received increased attention, especially in the arid western United States where thick unsaturated zones and highly heterogeneous sediment and fractured rock has led to the development of significant perched water zones (e.g., Nimmo et al. 2004; Wu et al. 2004; Robinson et al. 2011). A perched water zone in the subsurface is defined as a saturated zone that is above or not directly connected to the regional water table (Freeze and Cherry 1979). Perched water zones, containing accumulated water from natural or anthropogenic sources, are separated from the water table by unsaturated materials with depths varying from just a few (Kellin et al. 2009) to hundreds of meters (Wu et al. 2004). In these zones, the water phase pressure must be equal to or greater than static atmospheric gas pressure at the same elevation. Perching phenomena may occur in a permeable layer overlaying a relatively impermeable layer, in a well-connected fractured unit overlaying a locally unfractured or poorly connected fractured unit, or it may form along a sloped low-permeability layer adjacent to a fault acting as a capillary barrier 
to water flow (Wu et al. 1999). Perched water zones may be temporary or permanent features, depending on the hydraulic properties of the high- and low-permeability layers, the prevailing hydrologic conditions, and the effect of actions such as pumping.

According to Robinson et al. (2005), assessment of the impact of perched water on subsurface flow is one of the most difficult aspects of vadose zone characterization and modeling because perched water interferes with vertical flow and may lead to lateral diversion of infiltrating water. Perched water may represent an important subsurface pathway for facilitating contaminant transport from the ground surface to the regional aquifer and complicating contamination problems in several ways. Vertical flow of perched water through a low-permeability perching layer is a function of perched-water height as well as thickness and hydraulic conductivity of the low-permeability layer. Horizontally, there might be greatly increased flow, resulting in water and contaminant transport at a rate much faster than predicted based on bulk hydraulic properties and the traditional Richards' equation. Under these conditions, only a small fraction of the subsurface interacts with the contaminants, which limits adsorption and other attenuation processes (Nimmo et al. 2004). Another complication might be that, due to the nature of perched water, recharge to the water table at many sites may be spatially nonuniform (Robinson et al. 2011).

Most recent perched-water zone studies have been conducted in the context of contaminant transport; however, the effects of perching phenomena are also of interest in artificial recharge efforts (Flint et al. 2004, 2012) and for lateral flow on hillslopes (Uchida et al. 2004) and reclaimed soils (Kellin et al. 2004). Generally, artificial recharge projects apply water in surface and near-surface spreading locations, using the vadose zone to transport and store water. Flint et al. (2004) used a numerical analysis to demonstrate that recharge of the regional aquifer at San Gorgonio Pass, California, could be ineffective because most of the injected water would remain above a large perching zone, considerably delaying and limiting recharge to occur in relatively small areas. A follow-up study (Flint et al. 2012) showed that, after actual infiltration of almost 4 million $\mathrm{m}^{3}$ of water, vertical aquifer recharge was considerably larger than predicted. Water pressure measurements at the site indicated that the hydraulic conductivity of the lowpermeability layer was larger than originally assumed. The work by Flint et al. (2012) supports the importance of collecting pertinent site hydrological data to constrain the numerical predictions. Nearsurface perched-water zones have been observed on hillslopes with thin soil mantles overlaying bedrock (Uchida et al. 2004) and on reclaimed landscapes in oil sands regions in Canada where reclamation soil layers, with a thickness of approximately $1 \mathrm{~m}$, were deposited on saline-sodic shale overburdens (Kellin et al. 2009). For these cases, infiltration water moves vertically toward the soil-rock interface, followed by perching and lateral flow above the impeding bedrock or overburden material. Depending on the rainfall intensity and antecedent moisture conditions, a perched water table can develop at an interface, creating a saturated and highly mobile zone of water that has the ability to move laterally at considerable velocities. The topography of the impeding layer controls, to a large degree, the spatial distribution and path of the subsurface flow.

Perched-water zones at much greater depths affect flow and contaminant transport at a large number of arid U.S. Department of Energy (DOE) sites, such as Yucca Mountain (Wu et al. 1999, 2004), the Idaho National Engineering and Environmental Laboratory (INEEL; Nimmo et al. 2002, 2004; Duke et al. 2004; Wang et al. 2010), the Pantex Plant in Amarillo, Texas (Adam et al. 2004), and the Los Alamos National Laboratory (LANL; Birdsell et al. 2004; Robinson et al. 2005, 2011).

The modeling efforts by Wu et al. $(1999,2004)$ for the deep vadose zone at Yucca Mountain, which has been under consideration by DOE as a potential site for the storage of high-level radioactive waste, 
were calibrated with field hydrological data related to perched-water locations. The studies indicated considerable lateral flow toward faults, potentially bypassing large zones of zeolite layers that are thought to have substantial capacity to mitigate radionuclide releases. The simulations also showed that much larger infiltration rates likely occurred in the past to form the various perched-water zones in the subsurface.

The various perched-water zones at the INEEL were created mostly as the result of large fluxes of waste water (Nimmo et al. 2004). In most cases, the perched-water zones are temporary, persisting until horizontal and vertical flow spreads them out enough to leave the porous materials unsaturated. However, infiltration of waste water has also created perched contaminated zones that have persisted for several years. A tracer experiment by Nimmo et al. (2002) showed that substantial perching can take place within both sediments and basalts at permeable-impermeable contacts. The authors also concluded that although low-permeability layers divert water laterally at large Darcy velocities (up to $14 \mathrm{~m} /$ day), they do not prevent solute transport to the regional aquifer.

At the Pantex Plant site in Texas, a large perched-water zone has an area of more than $20 \mathrm{~km}^{2}$, containing almost 30 million $\mathrm{m}^{3}$ of water contaminated with pollutants such as trichloroethylene and chromium (Adam et al. 2004). Pumping to reduce water saturations has removed more than 7 million $\mathrm{m}^{3}$ and, in combination with an in situ bioremediation system, has enhanced degradation and attenuation.

Perched-water conditions occur beneath the Pajarito Plateau at 33 dispersed locations in the subsurface of the LANL (Robinson et al. 2005). An extensive set of observations made in deep wells makes this plateau one of the most studied vadose zones among research efforts targeted at understanding mechanisms that give rise to perched water and the hydraulics of perched-water zones (e.g., Birdsell et al. 2004; Kwicklis et al. 2005; Robinson et al. 2011). A large number of perched-water zones at LANL are located below wet canyons, suggesting that in addition to perching horizons, locally high percolation rates with values up to $1 \mathrm{~m} / \mathrm{yr}$ are required to yield saturated conditions (Kwicklis et al. 2005). Under dry canyons, perched water occurs on top of extensive low-permeability layers.

Modeling of flow and contaminant transport in perched-water zone environments has been conducted using mostly three-dimensional (3-D) modeling approaches, although lower-dimensional approaches can be feasible for some sites. Typically, it is the heterogeneous subsurface conditions that drive the need for a 3-D representation (e.g., Wu et al. 2004; Robinson et al. 2011; Flint et al. 2012). Wang et al. (2010) used a two-dimensional approach to simulate strontium 90 transport in the subsurface of the INEEL, justifying the approach by the large waste sites and the low-permeability features of the perching layers. Duke et al. (2007) used a one-dimensional approach to compute contaminant transport in perched water through a laterally extensive low-permeability zone in the INEEL subsurface. In this analysis, it was assumed that most of the waste water had moved downward and perched on top of a low-permeability perching layer and that lateral perched-water flow was minimal. Under these conditions, contaminants are transported primarily vertically through the perching layer, allowing for a one-dimensional analysis.

\subsection{B, BX, and BY Tank Farms}

Historical operations and waste release practices have led to contamination within the vadose zone and groundwater in the B, BX, and BY Tank Farms area (Figure 1). Currently, the majority of the $\mathrm{U}$ inventory is in the vadose zone $(6793 \mathrm{~kg})$; only a small amount $(22.3 \mathrm{~kg})$ is within the groundwater 
(Serne et al. 2010). The $\mathrm{U}$ in the vadose zone consists of a water-extractable portion $(2420 \mathrm{~kg})$ and a fraction that is only acid extractable (4373 kg; Serne et al. 2010). Thus, geochemical reactions within the vadose zone have rendered a portion of the $U$ relatively immobile (Serne et al. 2010). The potential future flux of $\mathrm{U}$ and Tc (also present in the B, BX, and BY Tank Farms area) into the groundwater and resulting groundwater plumes needs to be evaluated as part of remediation decisions at this site.

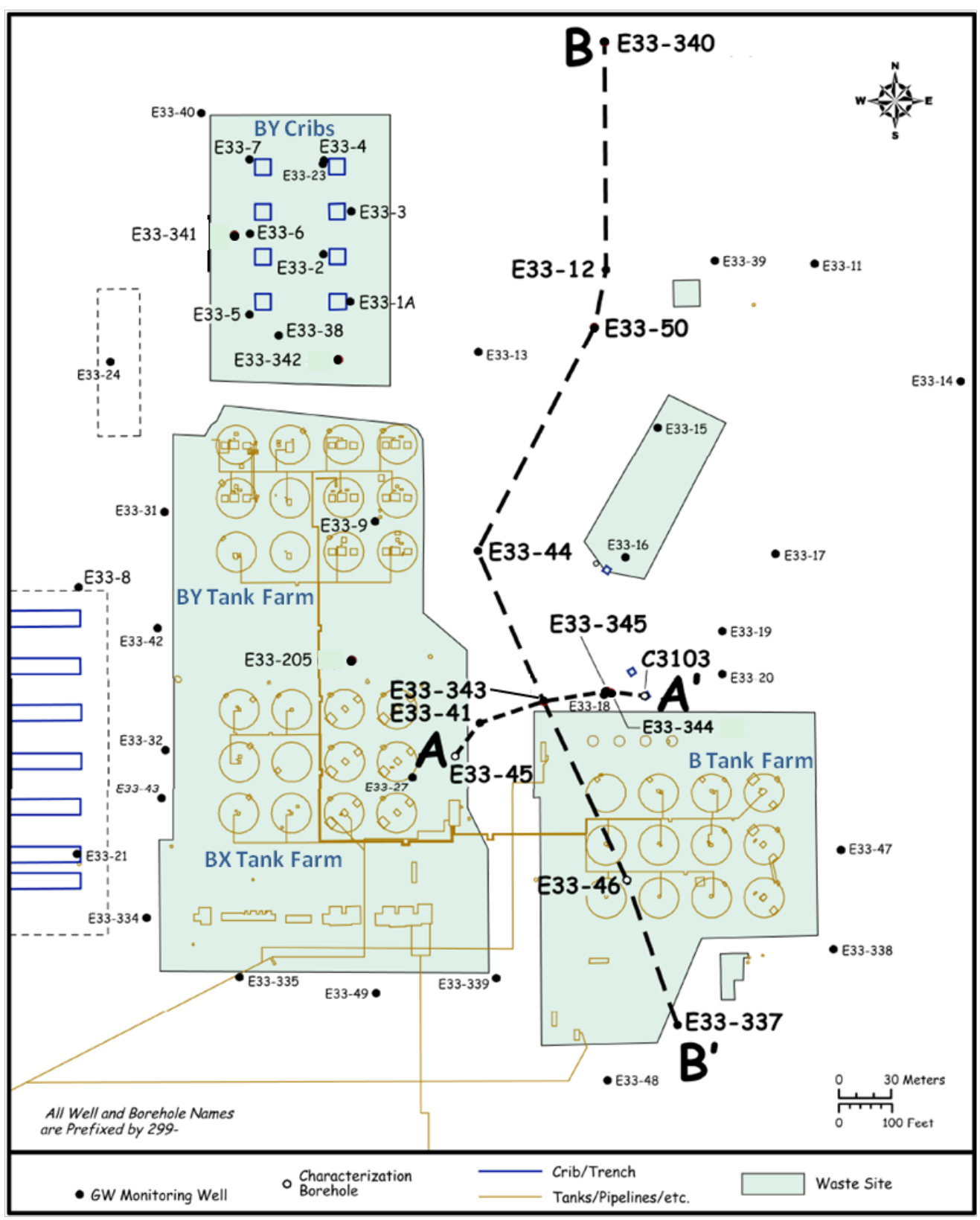

Figure 1. Site map indicating waste sites and well locations for the B, BX, and BY Tank Farms area (adapted from Serne et al. 2010).

Figure 2 presents the general stratigraphy of the sediments in the B, BX, and BY Tank Farms area. In this area, transition from the high-permeability Hanford formation (which consists of a thinner H1 unit nearer to ground surface and a thick $\mathrm{H} 2$ unit) to the CCU occurs deep in the vadose zone (at a depth of 


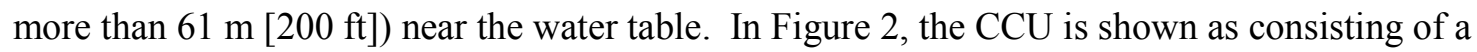
low-permeability portion, designated $\mathrm{CCUz}$, on top of a higher-permeability gravel zone, designated CCUg. The CCUz contains mixtures of silt and fine sand in varying proportions. A generalized conceptual stratigraphic model of the perched zone near wells 299-E33-344 and 299-E33-345 is shown in Figure 3. Here, the $\mathrm{CCUz}$ is further resolved into a high-silt-content lower perching zone (CCUz lower $)$ about $1.8 \mathrm{~m}$ thick, a 4.9-m-thick zone with higher sand content $\left(\mathrm{CCUz}_{\text {sand }}\right)$, and another silt zone (CCUz $z_{\text {upper }}$ ) about $1.8 \mathrm{~m}$ thick at the top of the CCUz (Williams et al. 2012). The CCUg unit contains a thin aquifer bounded by an underlying basalt formation.

Well 299-E33-344 (adjacent to well 299-E33-345, as shown in Figure 1) is screened within the perched-water zone and has about $3.36 \mathrm{~m}(11 \mathrm{ft})$ of perched water in the $\mathrm{CCUz}_{\text {sand. }}$. Figure 4 presents the observed water saturations from sediment sample analyses at wells 299-E33-344 and 299-E33-345. At

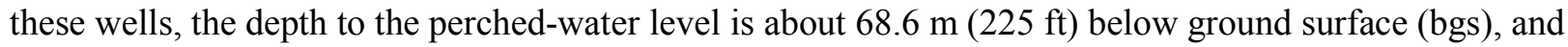
the depth to the regional groundwater table is about $78.4 \mathrm{~m}(257 \mathrm{ft}) \mathrm{bgs}$. Figure 5 (Serne et al. 2010) illustrates that the $\mathrm{CCUz}$ is present in only a portion of the B, BX, and BY Tank Farms area. Based on available borehole information, the perched water has been interpreted to roughly track the $6.1-\mathrm{m}$ (20-ft) CCUz thickness contour shown in Figure 5.

The volume of perched water can be estimated using observed information and reasonable assumptions. For an observed constant perched-water height of $3.36 \mathrm{~m}$ over an areal extent of $19,175 \mathrm{~m}^{2}$ (defined by the 6.1-m (20-ft) CCUz thickness contour of Figure 5), and an assumed porosity for the $\mathrm{CCUz}_{\text {sand }}$ of 0.252 (equivalent to the porosity of $\mathrm{H} 2$ unit sand [Serne et al. 2010]), the total volume of perched water is $1.62 \times 10^{7} \mathrm{~L}$. This estimate is more likely an upper-bound high estimate for the perchedwater volume because it assumes a constant perched water thickness across the entire interpreted areal extent. Borehole evidence suggests that the perched-water system has a "bowl" shape such that the perched-water is thinner toward the edges of the areal extent. Assuming, based on Figure 5, that the areal shape of the zone is approximately rectangular with one axis twice as long as the other and that the zone has either a parabolic or an elliptical bowl shape, the total volume of perched water can be estimated to be $1.08 \times 10^{7} \mathrm{~L}$ and $6.38 \times 10^{6} \mathrm{~L}$ for the parabolic and elliptical shapes, respectively. Based on the average $\mathrm{U}$ concentration of $50.1 \mathrm{mg} / \mathrm{L}$ in extracted perched-water samples between October 2011 and February 2013 , the upper-bound mass of $U$ in the perched water is about $800 \mathrm{~kg}$, assuming a constant perchedwater height of $3.36 \mathrm{~m}$, but only 530 and $320 \mathrm{~kg}$ for the parabolic and elliptical bowl-shaped perchedwater zones, respectively.

Perched-water extraction has been initiated and is ongoing in well 299-E33-344; cumulative removals through February 2013 total about $3.8 \times 10^{5} \mathrm{~L}$ (100,000 gal) (Figure 6). Relatively consistent extraction rates have been maintained over the past 1.5 years of operation, as would be expected with an areally extensive, persistent perched-water zone. Over this time period, the perched-water height has declined by a small amount (Figure 7). The change in average elevation of the perched water table from a period of no pumping in January 2012 through March 2012 to that for a period of no pumping in early October 2013 (see Figure 6) was a decrease of about $0.14 \mathrm{~m}$. For comparison, the estimated decrease in perchedwater height as a result of water removal of $3.8 \times 10^{5} \mathrm{~L}$ of water from pumping operations would be $0.08 \mathrm{~m}$ assuming a constant perched-water height of $3.36 \mathrm{~m}$, and 0.10 and $0.15 \mathrm{~m}$ for the assumed parabolic and elliptical bowl-shaped perched-water zones, respectively. Future observed water table elevations, as a function of cumulative water volume removal, will provide information about the shape of the perched-water zone and will help predict future pumping behavior. 


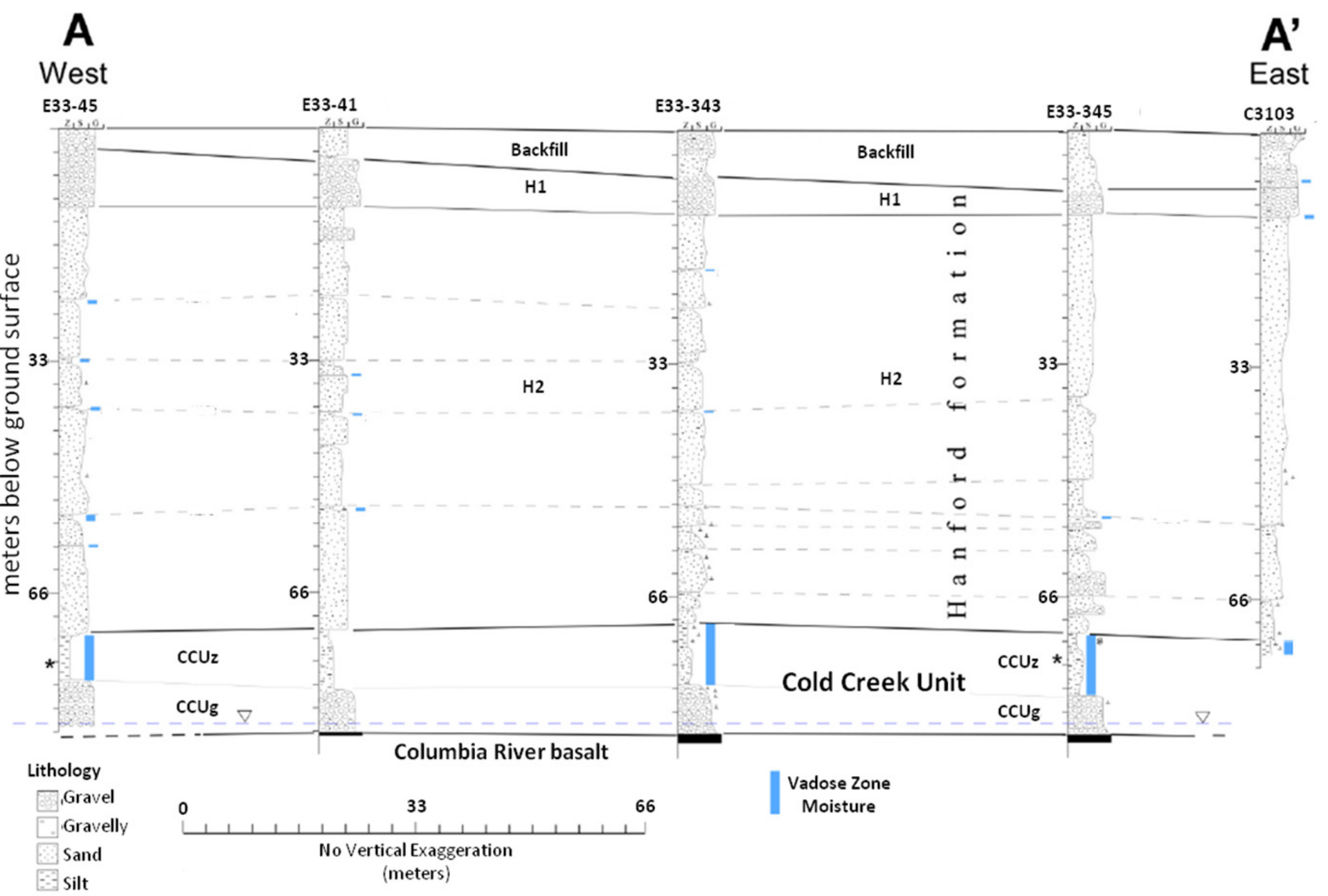

Figure 2. Generalized stratigraphy for the B-Complex area from Serne et al. (2010), cross section A-A' (Figure 1). High moisture conditions are indicated by the blue bar adjacent to the borehole logs; asterisks in the CCUz note locations where perched-water samples were obtained during drilling. 


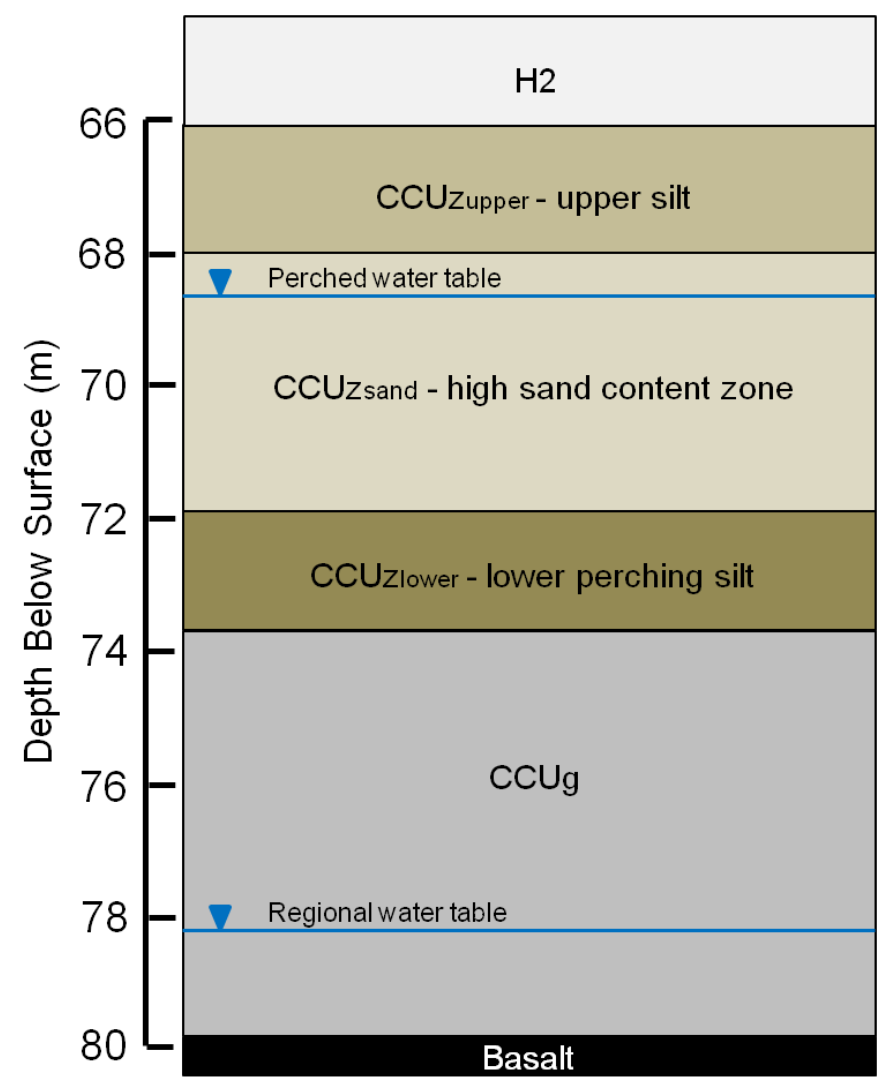

Figure 3. Generalized conceptual stratigraphic model of the perched-water zone near wells 299-E33-344 and 299-E33-345. The full thickness of the Hanford formation H2 unit is not depicted. The Cold Creek Unit silt (CCUz) in the area with perched water is comprised of a lower perching silt $\left(\mathrm{CCUz} \mathrm{z}_{\text {lower }}\right)$, a high sand content zone $\left(\mathrm{CCUz}_{\text {sand }}\right)$, and an upper silt zone $\left(\mathrm{CCUz}_{\text {upper }}\right)$. The Cold Creek Unit gravel (CCUg) contains the regional groundwater and is underlain by basalt.

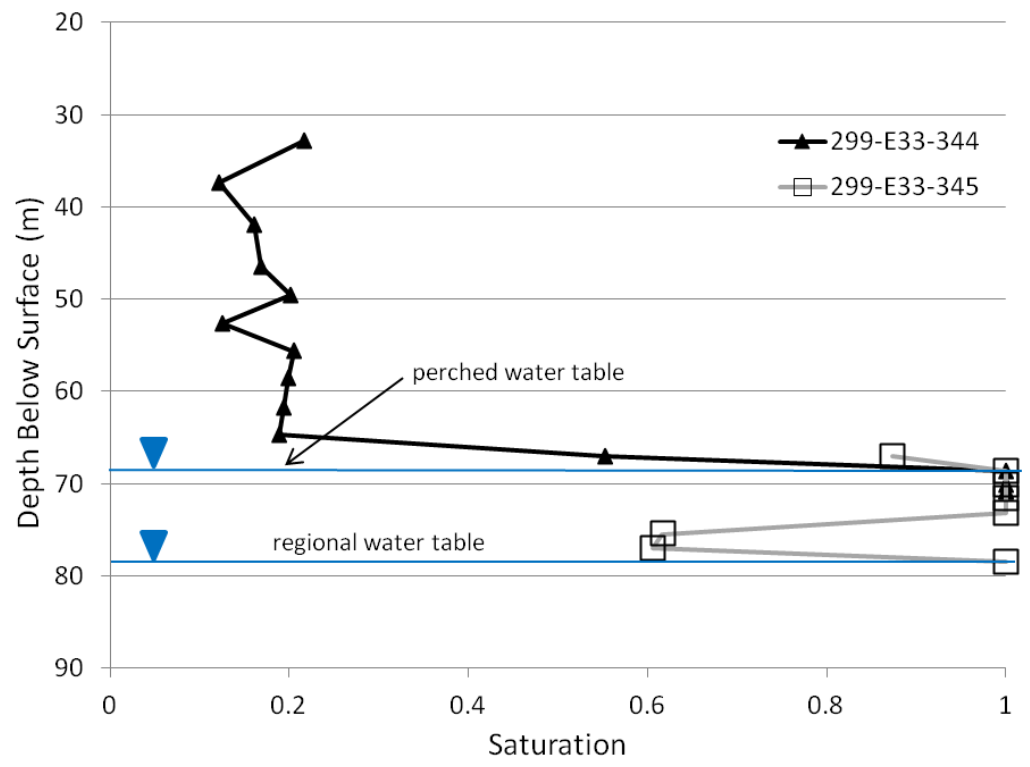

Figure 4. Observed water saturation with depth at adjacent wells 299-E33-344 and 299-E33-345 (Serne et al. 2010). 


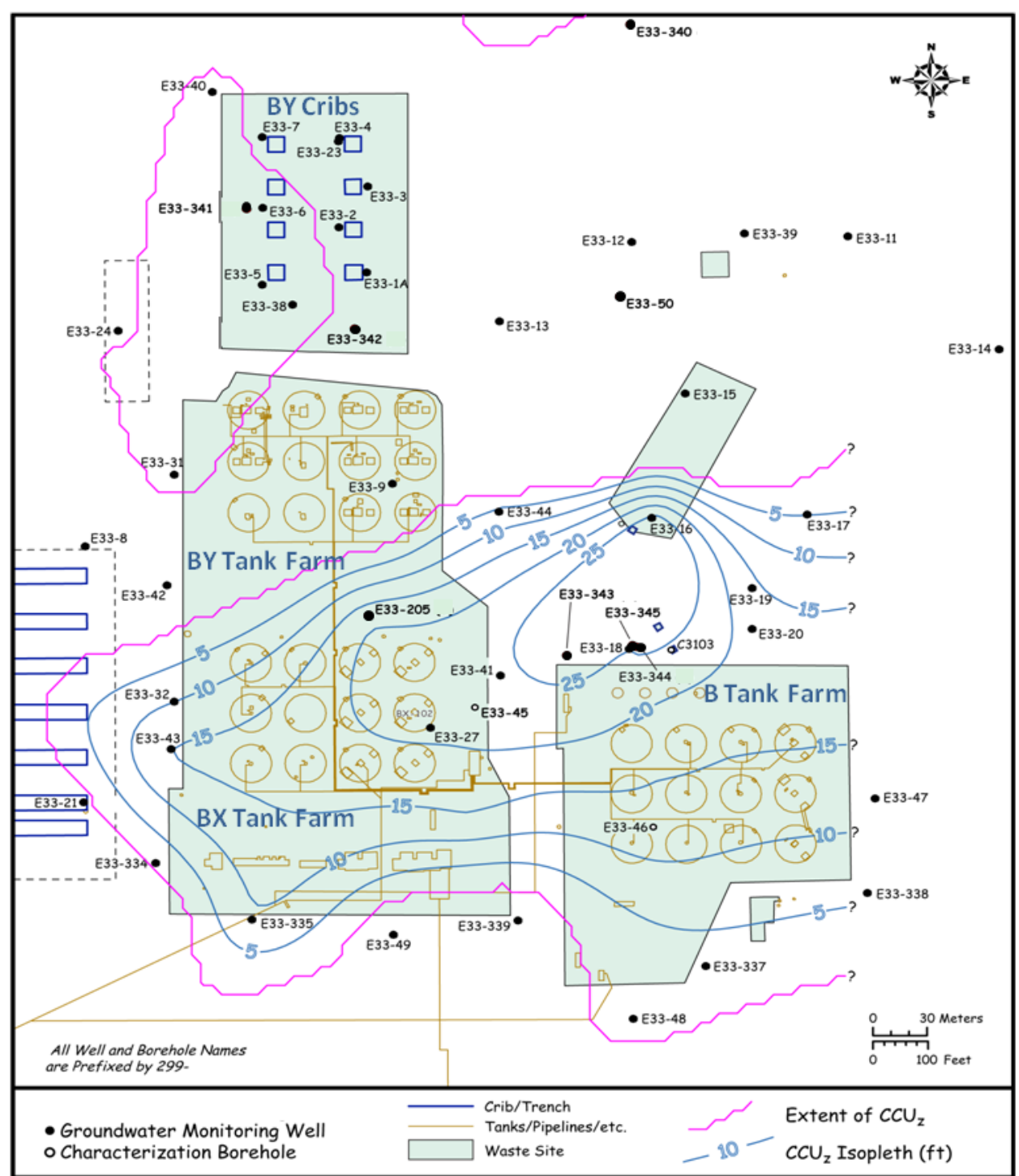

Figure 5. Cold Creek Unit silt (CCUz) thickness contour map (Serne et al. 2010). 


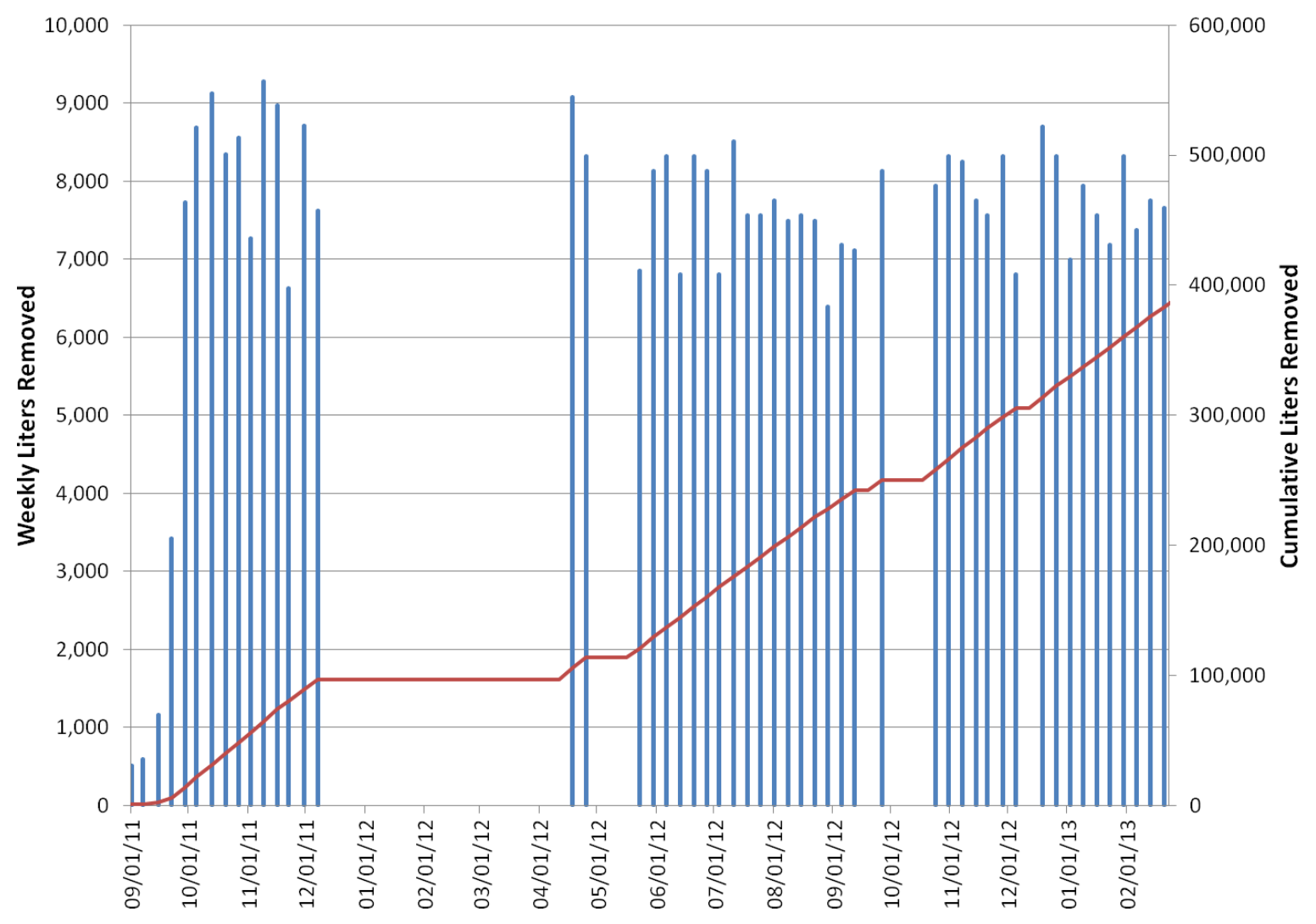

Figure 6. Water volume and extraction rates from the perched-water zone via well 299-E33-344.

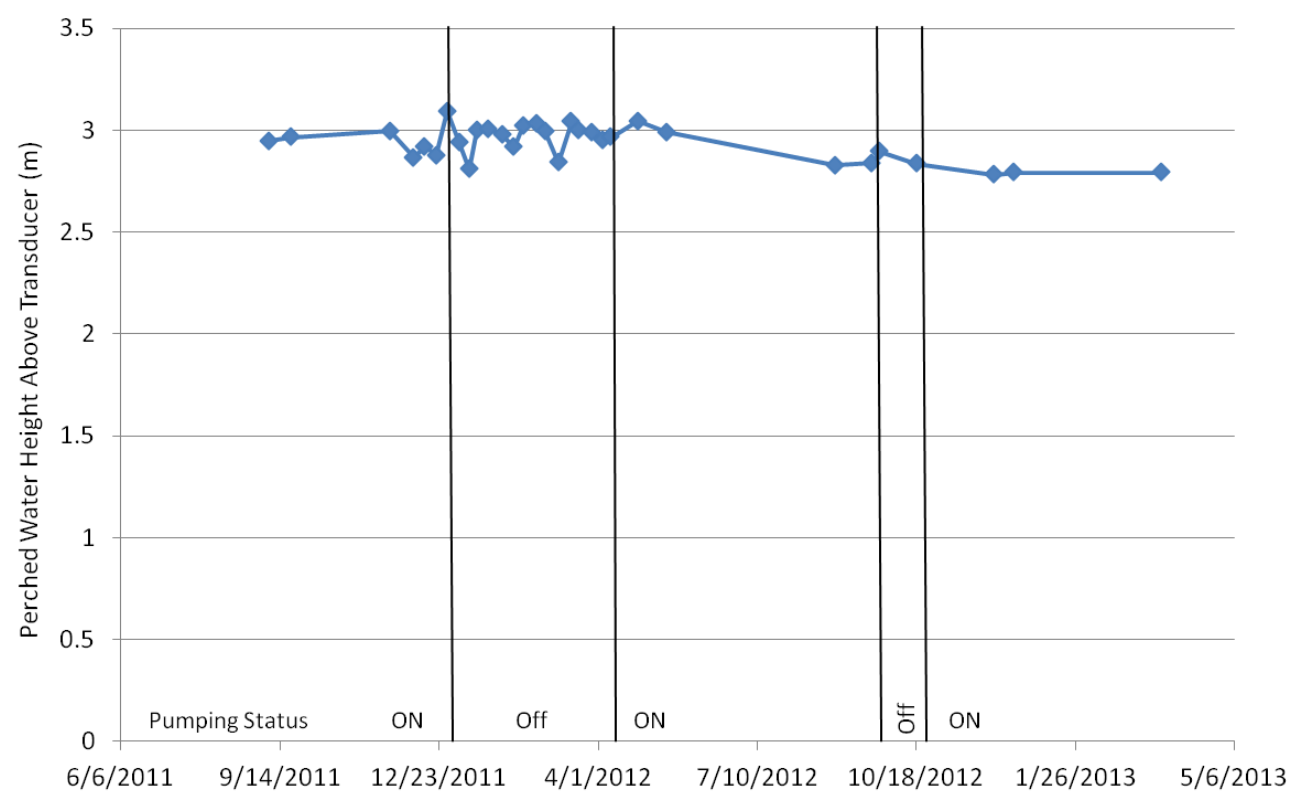

Figure 7. Perched-water height above the pressure transducer in well 299-E33-344. The transducer is located approximately $0.4 \mathrm{~m}$ above the top of the perching layer. 


\subsection{Approach and Methods}

This work performed an evaluation to better understand the future flux of contaminated water from the perched-water zone into the groundwater at the study site. The evaluation was conducted using two approaches: scoping calculations based on a modified version of Darcy's Law and numerical flow and transport simulations using the Subsurface Transport Over Multiple Phases (STOMP) code (White and Oostrom 2006).

\subsection{Darcy's Law Approach}

The scoping assessment was conducted using Darcy's Law to estimate perched-water height as a function of recharge rate and properties of the perching layer (e.g., CCUz lower in Figure 3) for steady-state conditions. This approach provides information on reasonable values of perching-layer hydraulic conductivity and site recharge rate and, therefore, guides the choice of parameter value ranges for the numerical simulation analysis. Assuming steady-state flow equal to the recharge rate, $R\left(\mathrm{LT}^{-1}\right)$, across the $\mathrm{CCU} z_{\text {lower }}$ layer with thickness, $L_{c}(\mathrm{~L})$, Darcy's Law can be written as

$$
R=K_{s a t, c} \frac{\left(L_{p}+L_{c}\right)}{L_{c}}
$$

where $L_{p}(\mathrm{~L})$ is the perched-water height on top of the $\mathrm{CCUz}_{\text {lower }}$ layer and $K_{\text {sat, },}$ is the saturated hydraulic conductivity $\left(\mathrm{LT}^{-1}\right)$ of the perching $\mathrm{CCUz}$ lower layer. It is apparent from Equation (1) that perching occurs only when $R>K_{s a t, c}$. It also follows directly from Equation (1) that a maximum $R$ value for a combination of $K_{s a t, c}$ and $L_{c}$ values for the $\mathrm{CCUz}_{\text {lower }}$ layer is given by

$$
R_{\max }=K_{s a t, c} \frac{\left(L_{p, \max }+L_{c}\right)}{L_{c}}
$$

where $L_{p, \max }$ is the maximum perched-water height. For the study site, where the values of $L_{c}$ and $L_{p, \max }$ are estimated to be approximately $1.83 \mathrm{~m}(6 \mathrm{ft})$ and $3.36 \mathrm{~m}(11 \mathrm{ft})$, respectively, it follows that $K_{\text {sat, } c}$ $<R<2.83 K_{\text {sat,c }}$ needs to be valid for perching to occur in the range of 0 to $3.36 \mathrm{~m}$. In our approach, perched-water heights are computed as a function of either $\mathrm{CCUz}_{\text {lower }}$ properties $\left(K_{s a t, c}\right.$ and $\left.L_{c}\right)$ or $R$ by arranging Equation (1) as follows:

$$
L_{p}=\frac{R L_{c}}{K_{s a t, c}}-L_{c}
$$

\subsection{Numerical Modeling Approach}

The water mode of the STOMP simulator (White and Oostrom 2006) was used to simulate vadose zone aqueous phase flow and contaminant transport to examine the effects of perched-water conditions. The fully implicit, integrated finite difference code has been used to simulate several laboratory and field contaminant transport systems (e.g., Zhong et al. 2008; Oostrom et al. 2010; Carroll et al. 2012). The 
applicable governing equations are the component mass-conservation equation for water and the solute transport equation, which is solved using a total-variation diminishing scheme.

A one-dimensional model was constructed to represent the subsurface configuration, as shown in Figure 3, near wells 299-E33-344 and 299-E33-345 (Figure 5). Given the large horizontal extent of the perching $\mathrm{CCUz}_{\text {lower }}$ layer and associated perched water (Figure 5), current flow and transport across this layer and into the water table is primarily vertical, justifying the one-dimensional approach. The length of the model extends from the land surface to regional water table at a depth of $78.39 \mathrm{~m}(257 \mathrm{ft})$. The domain was discretized into a uniform grid with a vertical cell length of $0.0305 \mathrm{~cm}(0.1 \mathrm{ft})$. Several grid refinement iterations were conducted leading to this grid discretization until no changes were observed in the water and contaminant fluxes across the perching layer and water table.

The numerical model was configured with six geologic sediment layers, according to Figure 3, with uniform material properties. Sediment property values and layer thickness information are listed in Table 1. The properties were obtained from a recently updated site conceptual model by Serne et al. (2010). The water retention values are for the van Genuchten saturation-water pressure constitutive model (van Genuchten 1980). The parameter values in Table 1 represent the base case properties for the perched-water simulations.

Based on the results of the scoping calculations using the Darcy Law approach, a series of numerical simulations was completed in which the $K_{\text {sat, }}$ value was varied over several orders of magnitude for $R$ values of $0.35 \mathrm{~cm} / \mathrm{yr}$, representing long-term conditions with a natural shrub-steppe vegetation, and $6 \mathrm{~cm} / \mathrm{yr}$, representing current conditions at the study site with disturbed surface conditions (Fayer et al. 2010). Each simulation consisted of two parts. In the first part, the steady-state flow conditions were computed for the imposed $R$ value. The results of this part were used to evaluate water saturations as a function of depth at steady state and provide the initial conditions for the subsequent transient flow and transport simulation where a 3.36-m perched-water height was imposed on top of the perched layer. The perched water zone was assumed to be fully saturated initially, containing non-sorbing Tc at a unit aqueous phase mass concentration. For simulations in which both non-sorbing Tc and sorbing $U$ solutes were considered, equal volumetric mass concentrations were specified in the perched water for both solutes to allow for a straightforward comparison of transport behavior. Water and contaminant fluxes out of the perched layer and into the groundwater were computed for several scenarios. The results for these scenarios are presented in Section 4.

Table 1. Overview of model values for sediment layer thickness, hydraulic property, longitudinal dispersivity, and uranium partition coefficient (Serne et al. 2010).

\begin{tabular}{lcccccccc}
\hline $\begin{array}{c}\text { Sediment } \\
\text { Layer }\end{array}$ & $\begin{array}{c}\text { Thick- } \\
\text { ness } \\
(\mathrm{m})\end{array}$ & $\begin{array}{c}\text { Hydraulic } \\
\text { Conductivity } \\
(\mathrm{cm} / \mathrm{s})\end{array}$ & $\begin{array}{c}\text { van Genuchten } \\
\alpha \\
(1 / \mathrm{cm})\end{array}$ & $\begin{array}{c}\text { van Genuchten } \\
n\end{array}$ & $\begin{array}{c}\text { Porosity } \\
(-)\end{array}$ & $\begin{array}{c}\text { Residual } \\
\text { Saturation } \\
(-)\end{array}$ & $\begin{array}{c}\text { Longitudinal } \\
\text { Dispersivity } \\
(\mathrm{cm})\end{array}$ & $\begin{array}{c}\text { Uranium } \\
\mathrm{K}_{\mathrm{d}} \\
(\mathrm{mL} / \mathrm{g})\end{array}$ \\
\hline $\mathrm{H} 1$ & 10.98 & $2.20 \times 10^{-4}$ & 0.0073 & 1.588 & 0.121 & 0.149 & 9 & 0.3 \\
$\mathrm{H} 2$ & 55.21 & $1.18 \times 10^{-4}$ & 0.0157 & 1.888 & 0.252 & 0.123 & 3.1 & 0.8 \\
$\mathrm{CCUz}_{\text {upper }}$ & 1.83 & $1.22 \times 10^{-5}$ & 0.0046 & 1.767 & 0.376 & 0.066 & 3.1 & 1.5 \\
$\mathrm{CCUz}_{\text {sand }}$ & 4.58 & $1.18 \times 10^{-4}$ & 0.0157 & 1.888 & 0.252 & 0.123 & 3.1 & 0.8 \\
$\mathrm{CCUz}_{\text {lower }}$ & 1.83 & $1.22 \times 10^{-5}$ & 0.0046 & 1.767 & 0.376 & 0.066 & 3.1 & 1.5 \\
$\mathrm{CCUg}$ & 4.58 & $3.08 \times 10^{-4}$ & 0.0061 & 1.571 & 0.121 & 0.085 & 3.1 & 0.26 \\
\hline
\end{tabular}




\subsection{Results and Discussion}

\subsection{Scoping Assessment}

A scoping assessment was conducted to estimate 1) perched water height $\left(L_{p}\right)$ as a function of recharge rate $(R)$ and $K_{\text {sat,c }}$ values, 2) steady-state vertical flux as a function of $L_{p}$, and 3 ) assess the impact of variations in the perching-zone properties on these estimates. Although base case estimates for hydraulic property values can be compiled from site characterization information, such as the data provided in Serne et al. (2010), the site-specific values of these properties at the perched-water location are uncertain. Conducting analyses for a range of potential saturated hydraulic conductivity values of the perching $\mathrm{CCUz}_{\text {lower }}$ layer $\left(K_{\text {sat,c }}\right)$ and system hydraulic conditions provides a set of estimates that can be compared to observed conditions as a means to assess these uncertainties.

An estimated $L_{p}$ as a function of $R$ and $K_{s a t, c}$ can be compared to field $L_{p}$ observations as one method of evaluating the site-specific conditions. As shown in Figure 8, a very high steady-state recharge rate would be needed for the base case $K_{s a t, c}$ value to produce the observed $L_{p}$ of $3.36 \mathrm{~m}$. Historical waste discharges, however, may have provided sufficient transient increases in the effective infiltration rate to cause the observed perched-water zone. Figure 8 also shows a calculation of the volume of temporary water discharge needed to produce perched water as a function of the hydraulic conductivity of the perching layer. In Figure 8, alternative $x$-axis values are calculated to convert the recharge rate to a volumetric discharge rate by multiplying the estimated perched-water area of $19,175 \mathrm{~m}^{2}$ (based on the CCUz 6.1-m [20-ft] thickness contour shown on Figure 5) and then multiplying the discharge rate per year by 50 years. The computed volumes are useful to consider with respect to estimates of historical transient water and waste discharges and constrain the range of possible $K_{s a t, c}$ values. The extremely large recharge rates or temporary discharge volumes needed to achieve perched water with the higher $K_{\text {sat, }}$ values are unlikely to have occurred or be continuing to occur in the B, BX, and BY Tank Farms area. For the higher $K_{s a t, c}$ values evaluated, with cessation of these high water inputs, perched-water height would rapidly begin to dissipate as discussed below, inconsistent with the observed relatively stable perched-water conditions.

The $L_{p}$ and $K_{\text {sat,c }}$ parameters are the controlling factors for the water and associated contaminant fluxes to groundwater during the time when perched water is present. If the recharge rate has been reduced from conditions that created the perched water, the thickness of the perched-water zone will decrease over time. Although perched water is present, the vertical flux to groundwater will be equal to the recharge rate shown in Figure 8 for a given combination of $L_{p}$ and $K_{s a t, c}$. For the base case $K_{\text {sat,c, water }}$ flux to groundwater is high for all of the plotted perched-zone heights. Without continuation of an extremely high recharge rate to sustain the perched-water zone, the perched-water height would be expected to rapidly decrease over time under the base case conditions (Table 1). For recharge rates between 0.35 and $6 \mathrm{~cm} / \mathrm{yr}$, more representative of the range of surface conditions at the Hanford Site (Fayer et al. 2010), perched water is formed with only lower perching-layer hydraulic conductivity values.

It is also important to evaluate the height of perched water that would be expected under future steady-state recharge conditions (i.e., with no excess water or waste discharge at the surface). This type of estimate helps indicate the perched-water conditions that will exist when the vadose zone is in equilibrium with the recharge rate and the water flux to groundwater is again equal to the recharge rate after the increase in water flux induced by added water pulses has dissipated. The $L_{p}$ value was computed 
for a range of potential future steady-state $R$ values and as a function of $K_{\text {sat,c. }}$ As shown in Figure 9, perched conditions are expected to be present only for recharge rates at or below $17.2 \mathrm{~cm} / \mathrm{yr}$ (average annual precipitation rate; Fayer et al. 2010) starting at hydraulic conductivity values that are a small fraction of the base case value of $1.22 \times 10^{-5} \mathrm{~cm} / \mathrm{s}$ obtained from Serne et al. (2010). Because the value of $K_{s a t, c}$ is uncertain across several orders of magnitude, it is important to use other analyses to constrain the value of the hydraulic conductivity and enable use of Figure 9 as an estimate of future steady-state perched-water conditions as a function of $R$. Figure 9 also shows the effect of perching-layer thickness $\left(L_{c}\right)$ on computed $L_{p}$ values for the $6-\mathrm{cm} / \mathrm{yr}$ recharge example. Compared to the effects of recharge rate, a reasonable variation in $L_{c}$ results in only relatively small changes in $K_{s a t, c}$ needed for a given $L_{p}$ value.

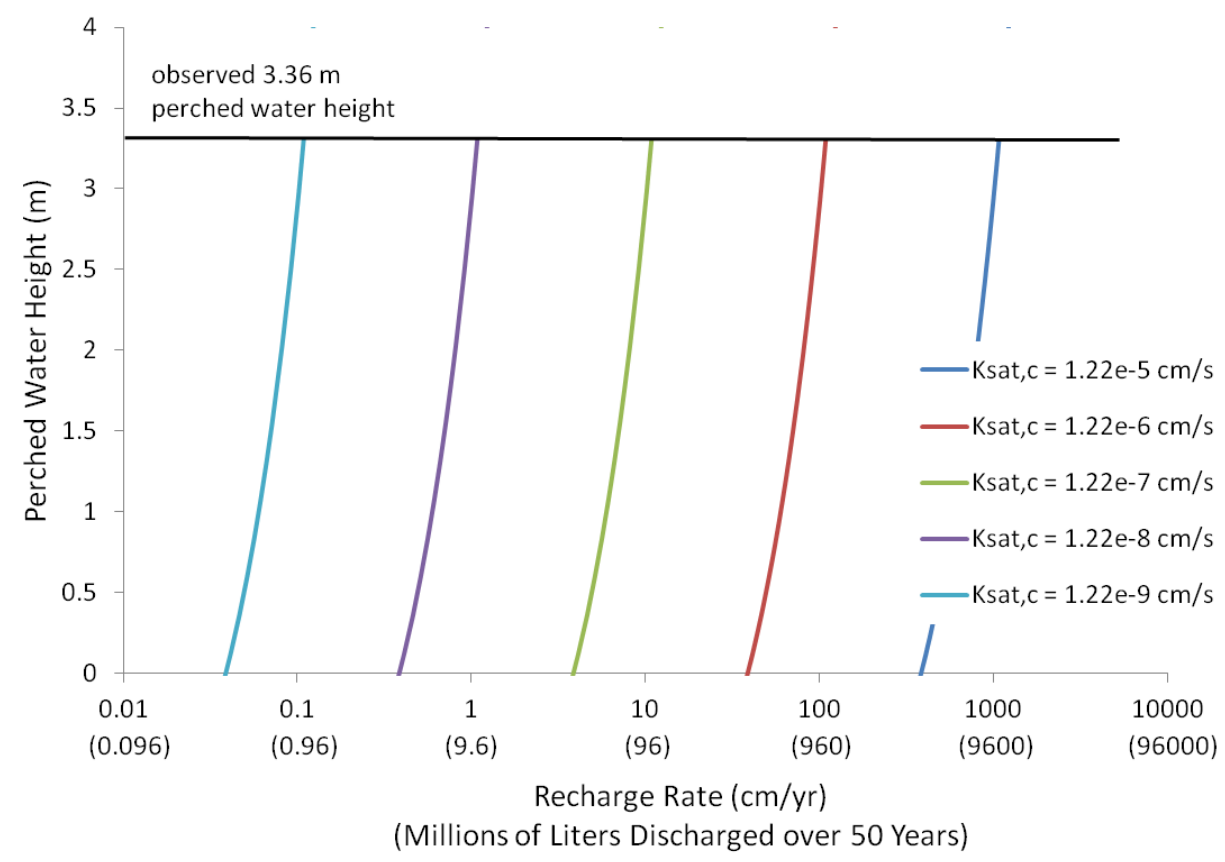

Figure 8. Perched-water height $\left(L_{p}\right)$ as a function of recharge rate $(R)$ and millions of liters discharged (over a 50-year period) for selected perching-layer-saturated hydraulic conductivity $\left(K_{\text {sat,c }}\right)$ values. The $K_{\text {sat,c }}$ value of $1.22 \times 10^{-5} \mathrm{~cm} / \mathrm{s}$ represents the base case. 


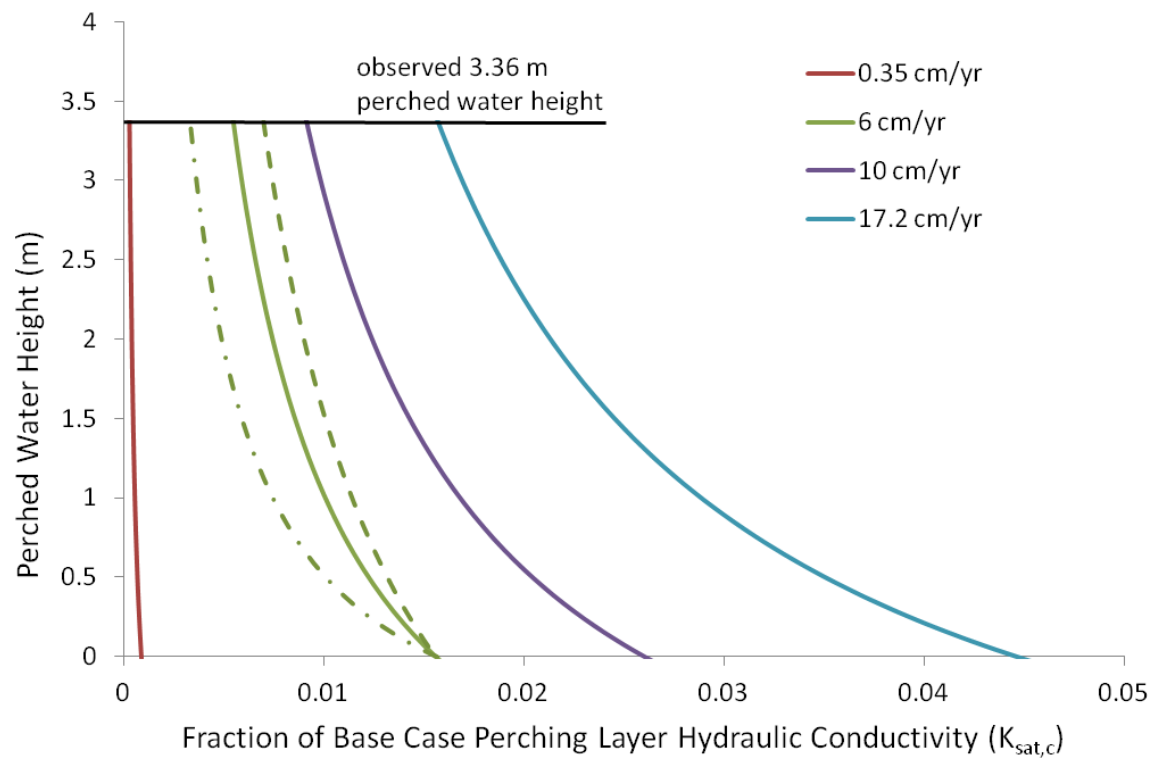

Figure 9. Perched-water height $\left(L_{p}\right)$ as a function of perching-layer-saturated hydraulic conductivity $\left(K_{\text {sat }, c}\right)$ reduction from the base case value of $1.22 \times 10^{-5} \mathrm{~cm} / \mathrm{s}$ and the recharge rate. Solid lines are for a perching-layer thickness $\left(L_{c}\right)$ of $1.83 \mathrm{~m}$. Dashed lines are for $L_{c}$ values of $0.92 \mathrm{~m}$ (left) and $2.75 \mathrm{~m}$ (right) for a $6-\mathrm{cm} / \mathrm{yr}$ recharge rate.

\subsection{Numerical Simulation Assessment}

The numerical model domain accounts for conditions above, within, and below the perched-water zone in simulating water saturation conditions and water and contaminant fluxes. In addition, the numerical simulations provide the ability to examine the perched-water system under transient conditions. Primary simulation results are estimates of 1) how perched-water height is expected to change over time and 2) the temporal dynamics of water and solute flux from the vadose zone to the groundwater.

Numerical simulations were conducted to estimate the water saturation conditions within each of the identified layers of the vadose zone for imposed recharge rates of 0.35 and $6 \mathrm{~cm} / \mathrm{yr}$ and for variations in the hydraulic conductivity of the perching layer. These simulation results provide an estimate of the water saturation distribution that would be expected once the perched-water zone dissipates and the distribution returns to the equilibrium conditions controlled by the recharge rate. That is, because the perched-water zone was developed due primarily to a previous perturbation from waste and water disposal to the vadose zone, the perched-water zone is expected to decline, and moisture conditions will return to the moisture content distribution controlled by the recharge rate under more "natural" conditions (e.g., no waste and excess water disposal at the ground surface). Figure 10 shows the water saturation profiles for steady-state simulation predictions. Note that for each of the imposed recharge rates of 0.35 and $6 \mathrm{~cm} / \mathrm{yr}$, perched-water conditions occur for only the lower two $K_{s a t, c}$ values. For the lowest considered value, the simulated $L_{p}$ value is considerably larger than the observed value of $3.36 \mathrm{~m}$.

Figure 11 shows the predicted transient response in $L_{p}$ over time for recharge rates of 0.35 and $6 \mathrm{~cm} / \mathrm{yr}$ and selected variations in $K_{\text {sat, }}$. In these simulations, a perched-water height of $3.36 \mathrm{~m}$ was imposed as an initial condition within the modeling domain to observe the transient dissipation in perching height from this condition. Simulations did not attempt to replicate the processes that caused the 
transient perched-water conditions. The simulation results suggest that $L_{p}$ will decline over time with a

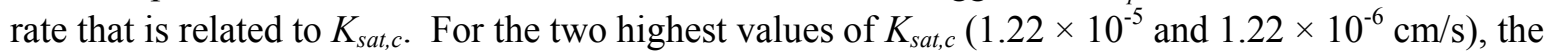
decline is predicted to occur rapidly ( $<1$ year) for both $R$ values, which is inconsistent with field observations (unless there is still considerable influx of water to maintain the perched-zone height). Observations during current perched-water pumping indicate a much slower rate of decline, more consistent with a value for the $K_{s a t, c}$ at the lower end of the simulated range. Figure 11 also shows the $K_{\text {sat, }}$ that would result in a stable 3.36-m perched-water height for both imposed recharge rates. In addition, the recharge rate that would result in a stable 3.36-m perched-water height for a specified $K_{\text {sat, }}$ $\left(1.22 \times 10^{-8} \mathrm{~cm} / \mathrm{s}\right.$ in Figure 11a and $1.22 \times 10^{-7} \mathrm{~cm} / \mathrm{s}$ in Figure $\left.11 \mathrm{~b}\right)$ is shown. These cases provide a perspective on the sensitivity in $K_{s a t, c}$ and $R$ for interpreting the transient behavior of the perched water table.

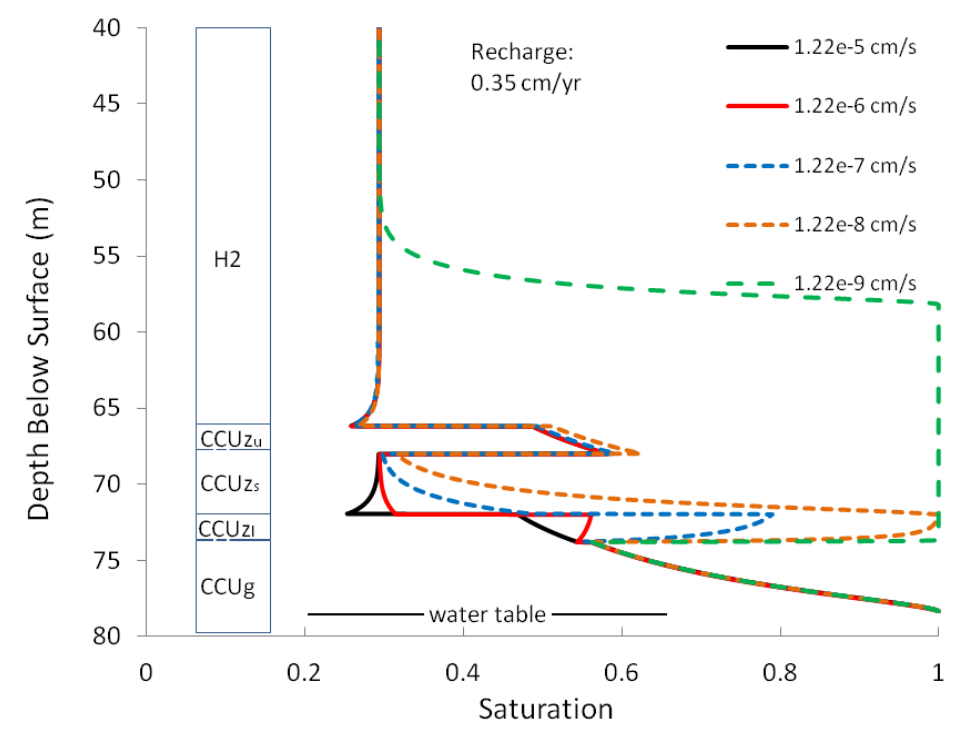

a)

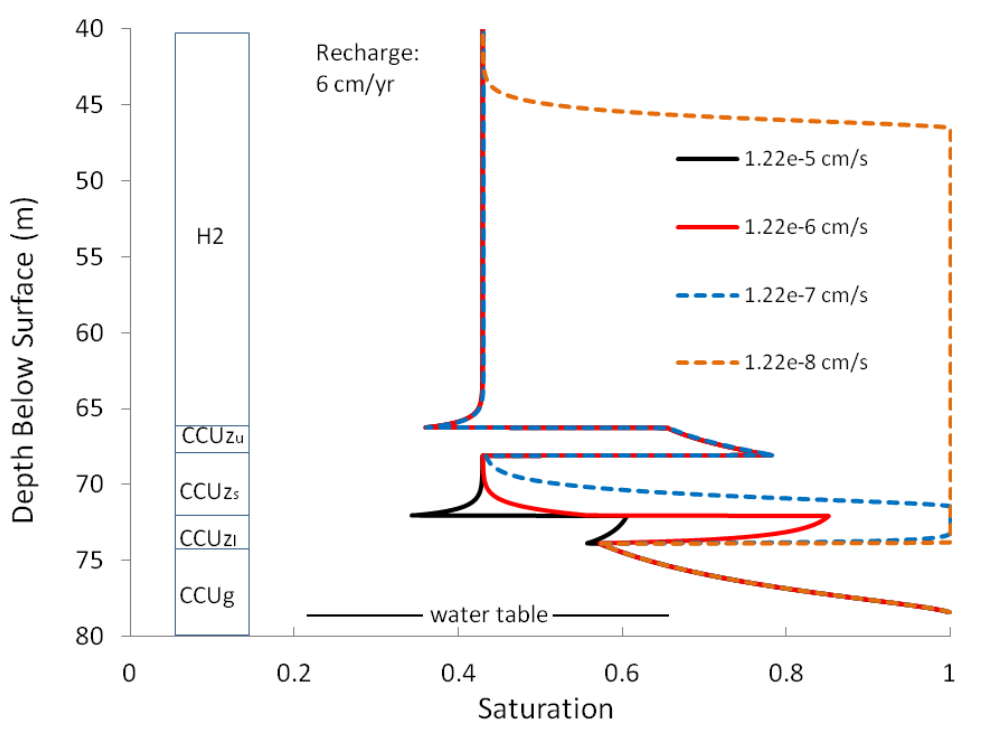

b)

Figure 10. Predicted steady-state water saturation distribution with depth for selected perching-layersaturated hydraulic conductivity $\left(K_{\text {sat,c }}\right)$ values and a recharge rate of a) $0.35 \mathrm{~cm} / \mathrm{yr}$ and b) $6 \mathrm{~cm} / \mathrm{yr}$. 


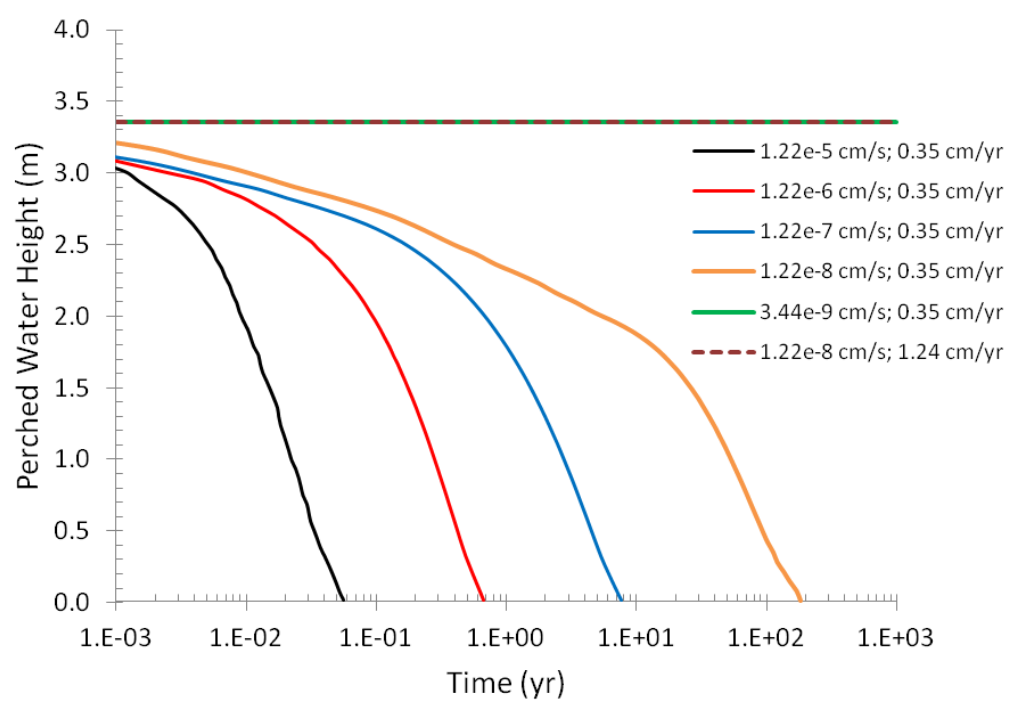

a)

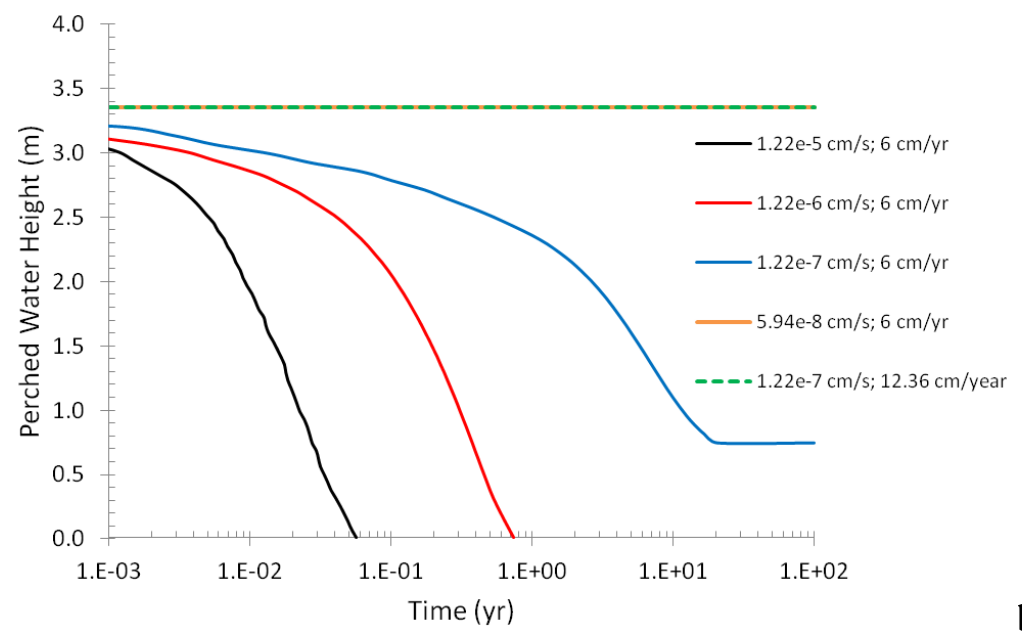

b)

Figure 11. Simulated perched-water height $\left(L_{p}\right)$ starting from an imposed initial perched-water height of $3.36 \mathrm{~m}$ for selected perching-layer-saturated hydraulic conductivity $\left(K_{s a t, c}\right)$ values and a recharge rate $(R)$ of a) $0.35 \mathrm{~cm} / \mathrm{yr}$ and b) $6 \mathrm{~cm} / \mathrm{yr}$. Examples of combinations of $R$ and $K_{\text {sat, }}$ values resulting in a stable $L_{p}$ of $3.36 \mathrm{~m}$ are also shown.

Simulation results also included a prediction of the water flux out the bottom of the perching layer and to groundwater for the imposed initial perched-water height of $3.36 \mathrm{~m}$ and subsequent transient response for selected variations in $K_{\text {sat, }}$ (Figure 12). The water flux to the groundwater for the perchedwater conditions is elevated over the water flux expected at equilibrium with a $0.35-\mathrm{cm} / \mathrm{yr}$ recharge rate for about 10 to 300 years for highest and lowest $K_{s a t, c}$ values, respectively. For a $6-\mathrm{cm} / \mathrm{yr}$ recharge rate, the range of elevated water flux is from about 3 to 200 years for highest and lowest $K_{\text {sat,c }}$ values, respectively. The elevated water flux is due to drainage of the perched-water zone and subsequent continued drainage of moisture as the vadose zone moisture conditions return to the equilibrium conditions driven by the imposed recharge rate. Except during the initial year, the water flux to the groundwater is a factor of two or less higher than the equilibrium recharge-driven water flux when the $K_{s a t, c}$ is at the low end of the range simulated. At the higher values of $K_{s a t, c}$, the water flux within the first 1 to 10 years is substantially higher, although shorter-lived due to the rapid dissipation of the perched 
conditions and rapid subsequent decreases in the water saturations. These results, in the context that the surface waste and water disposal was terminated in the past, suggest that the flux to groundwater may currently be at the highest level and near-term remediation actions to remove perched water will be more effective than those implemented later. However, for low $K_{s a t, c}$ values, the impact of the perched water on the water flux to the groundwater is relatively small.

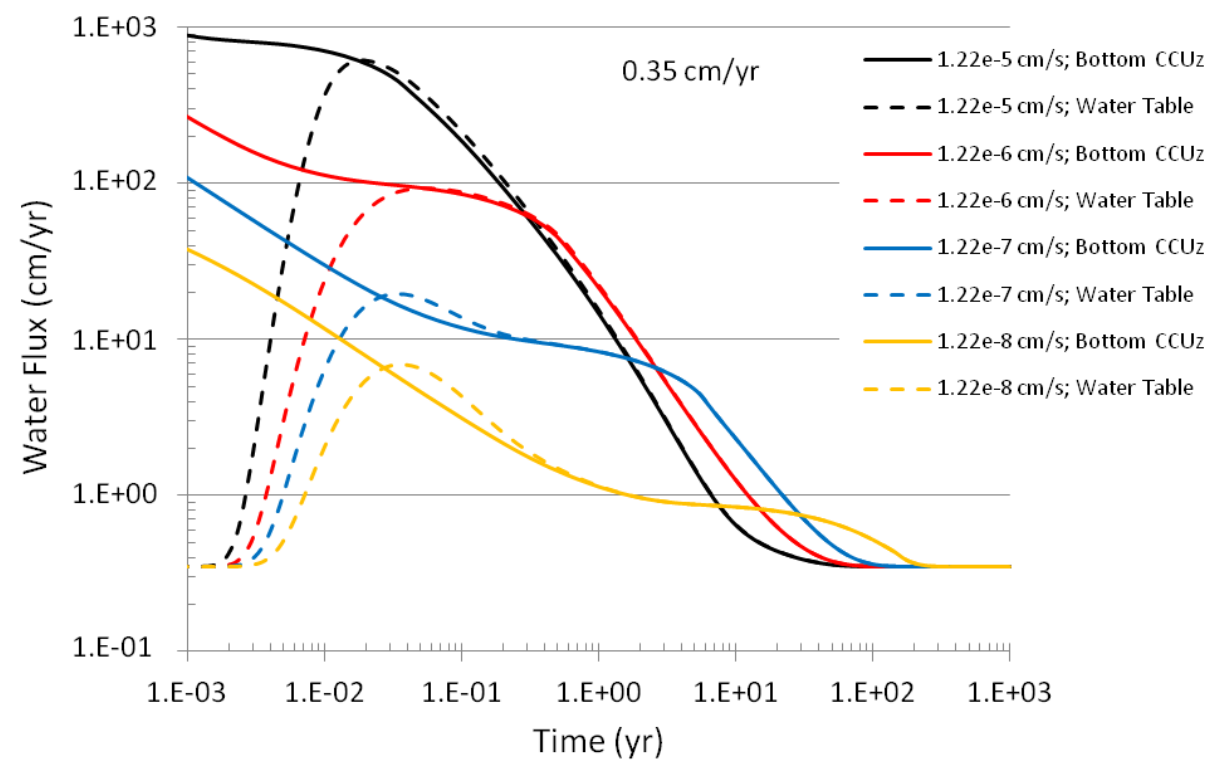

a)

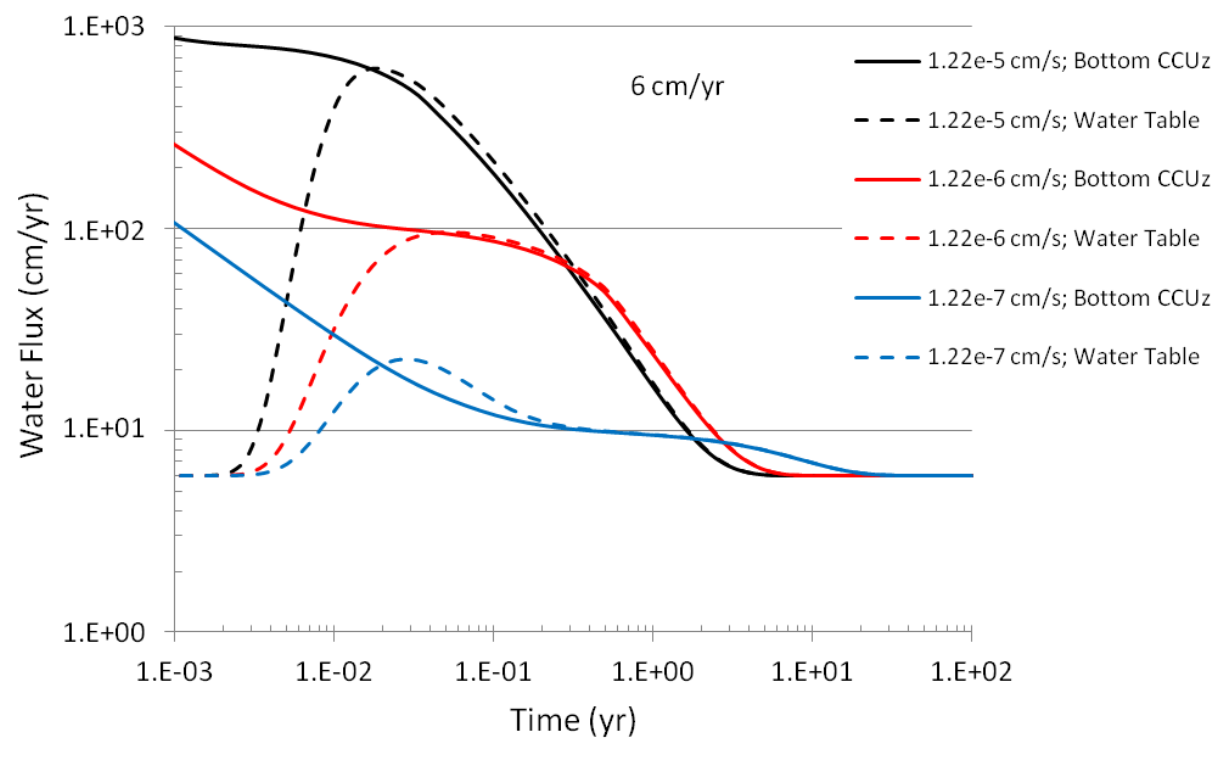

b)

Figure 12. Simulated transient water flux $\left(\right.$ over $1 \mathrm{~m}^{2}$ ) out the bottom of the perching layer (bottom $\mathrm{CCUz}$ ) and to groundwater (water table) with an imposed initial perched-water height $\left(L_{p}\right)$ of $3.36 \mathrm{~m}$ for selected perching-layer-saturated hydraulic conductivity $\left(K_{\text {sat, }}\right)$ values and a recharge rate $(R)$ of a) $0.35 \mathrm{~cm} / \mathrm{yr}$ and b) $6 \mathrm{~cm} / \mathrm{yr}$.

Simulations also included an evaluation of non-sorbing contaminant transport where contaminant as a solute was added only to the perched water above the perching layer (i.e., in the $\mathrm{CCUz}_{\text {sand; }}$; Figure 3 ). 
Contaminants are present within other regions of the vadose zone for the B, BX, and BY Tank Farms area. However, the simulations were focused on the impact of contaminants within the perched water because it is the target for current remediation efforts. Figure 13 shows predictions of non-sorbing contaminant flux out the bottom of the perching layer and to groundwater for the imposed initial perchedwater height of $3.36 \mathrm{~m}$ and subsequent transient response for selected variations in $K_{\text {sat, }}$. Contaminant

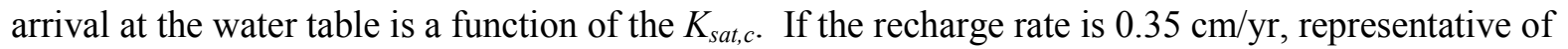
returning recharge to pre-Hanford Site levels, the contaminant flux into the groundwater is spread over hundreds of years and with a lower maximum flux than the maximum flux for the 6-cm/yr recharge results. With a recharge rate of $6 \mathrm{~cm} / \mathrm{yr}$, representative of current disturbed surface conditions, contaminant flux from the perched water occurs over a smaller time interval of tens of years. Thus, although perched water is present, the recharge rate is important in determining the nature of the contaminant flux to groundwater. Note that there is a delay between flux out the bottom of the perching layer and the flux into the groundwater, which is a function of the CCUg properties, saturation, and transport distance to the water table.

Figure 13 shows predictions for non-sorbing contaminant flux with no accelerated removal of perched water over time through active extraction (pumping). To examine the impact of active perched-water extraction on contaminant flux to groundwater, simulations were conducted to estimate the contaminant flux in which the $L_{p}$ was decreased to the steady-state height for $6-\mathrm{cm} / \mathrm{yr}$ recharge and a $K_{s a t, c}$ of $1.22 \times$ $10^{-7} \mathrm{~cm} / \mathrm{s}$. Figure 14 shows a comparison of the non-sorbing contaminant flux for the case with no perched water extraction $\left(L_{p}=3.36 \mathrm{~m}\right)$ and with active extraction (simulated as immediate removal) of about $75 \%$ of the perched water (steady-state $L_{p}=\sim 0.8 \mathrm{~m}$ ). A significant portion of the contaminant mass transported to the groundwater is removed through active perched-water extraction. However, the peak concentration in groundwater, corresponding to the peak contaminant flux in Figure 14, shows only moderate reduction. Note also that contaminant arrival times are not significantly impacted by active perched-water extraction for the simulated scenario.

Interpretation of the transport timeframe in the previous results must consider that simulations were for a non-sorbing contaminant such as Tc. Sorption of contaminants will slow transport and impact the resulting contaminant flux to groundwater. Figure 15 shows a comparison of contaminant flux to groundwater for a non-sorbing contaminant $(\mathrm{Tc})$ and for a sorbing contaminant in which $\mathrm{U}$ is used as the example with assigned $K_{d}$ values according to Table 1 . For the example with a $6-\mathrm{cm} / \mathrm{yr}$ recharge and a $K_{\text {sat, }}$ of $1.22 \times 10^{-7} \mathrm{~cm} / \mathrm{s}$, sorption spreads the contaminant flux over centuries compared to decades for the non-sorbing contaminant and also lowers the maximum contaminant flux. Note also that sorption also significantly decreases the contaminant flux to groundwater and would thereby also result in lower groundwater concentrations. The contaminant flux estimates from this study examine future fluxes from contaminants currently located in the perched water. Historical higher flux conditions during discharges, preferential pathways such as well casings, and/or other transport pathways not associated with the perched-water system may have contributed to the currently observed U plume in the B, BX, and BY Tank Farms area groundwater. Thus, the existence of the current plume can be consistent with the future flux predictions in Figure 15. For comparison, a $U$ flux was estimated based on available groundwater $U$ mass estimates. Taking the difference in the estimated groundwater $U$ masses of $22.3 \mathrm{~kg}$ and $3.4 \mathrm{~kg}$ in the years 2009 and 2000, respectively (Serne et al. 2010), and dividing by the nine-year timeframe yields an estimated $U$ mass flux from the vadose zone to the groundwater of $2.1 \mathrm{~kg} / \mathrm{yr}$. An estimated $\mathrm{U}$ mass flux from the vadose zone to the groundwater of $5.6 \mathrm{~kg} / \mathrm{yr}$ can be calculated using the maximum predicted flux 
from Figure 15 of about $0.0161 / \mathrm{m}^{2}$ day converted to account for the average $50.1 \mathrm{mg} / \mathrm{L}$ observed perched-water $U$ concentration and the estimated $19,175 \mathrm{~m}^{2}$ perched-water area.

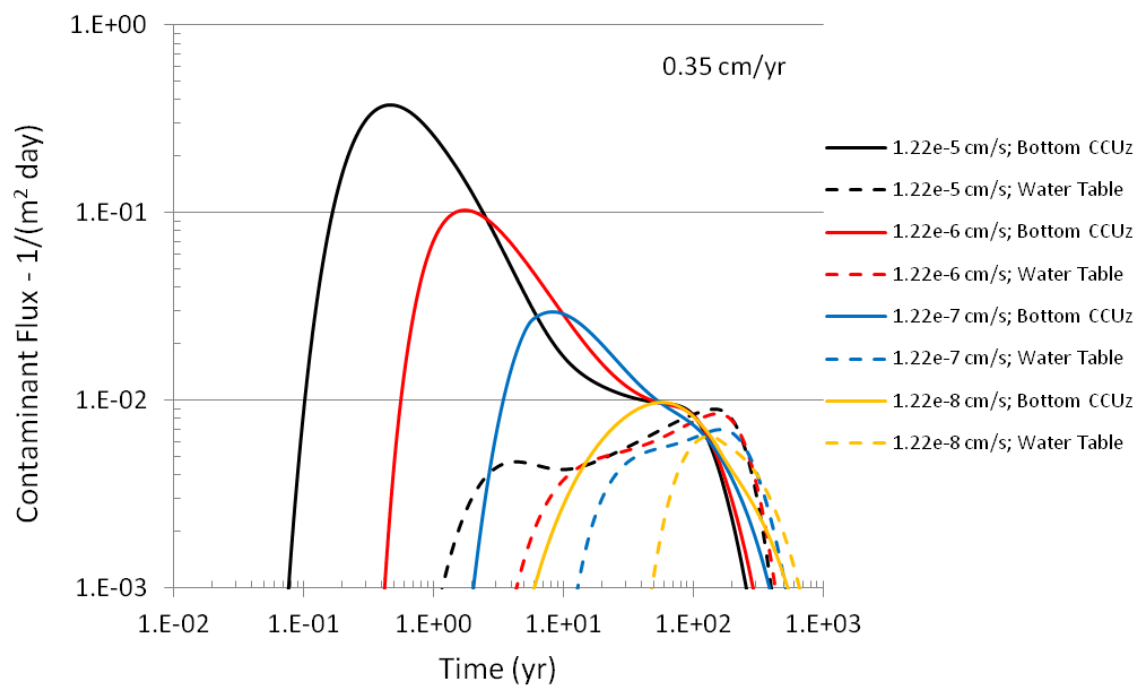

a)

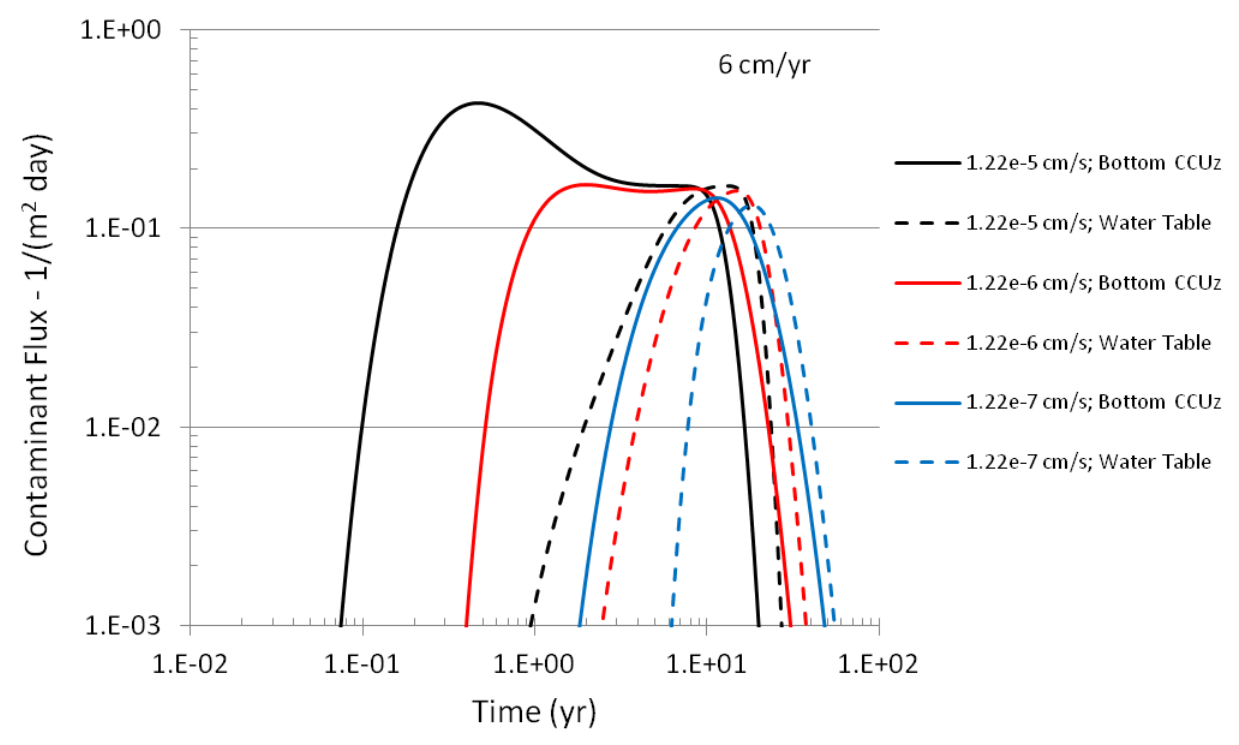

b)

Figure 13. Simulated transient contaminant flux out the bottom of the perching layer (bottom CCUz) and to groundwater (water table) with an imposed initial perched-water height $\left(L_{p}\right)$ of $3.36 \mathrm{~m}$ for selected perching-layer-saturated hydraulic conductivity $\left(K_{\text {sat,c }}\right)$ values and a recharge rate $(R)$ of a) $0.35 \mathrm{~cm} / \mathrm{yr}$ and b) $6 \mathrm{~cm} / \mathrm{yr}$.

Although not explicitly modeled in this study, a combination of perched-water removal by pumping and recharge reduction could reduce the contaminant flux further by decreasing the water flux to lower than $6 \mathrm{~cm} / \mathrm{yr}$. At some point, this reduction may create conditions where the resulting $U$ concentrations in groundwater are below groundwater protection goals. Note that these transport analyses used a unit concentration approach and a one-dimensional analysis. Additional study with a multidimensional model would be necessary to evaluate the coupled vadose zone-groundwater system with actual contaminant 
concentrations and simulation of resultant groundwater plume behavior as a function of vadose zone perched-water and recharge conditions.

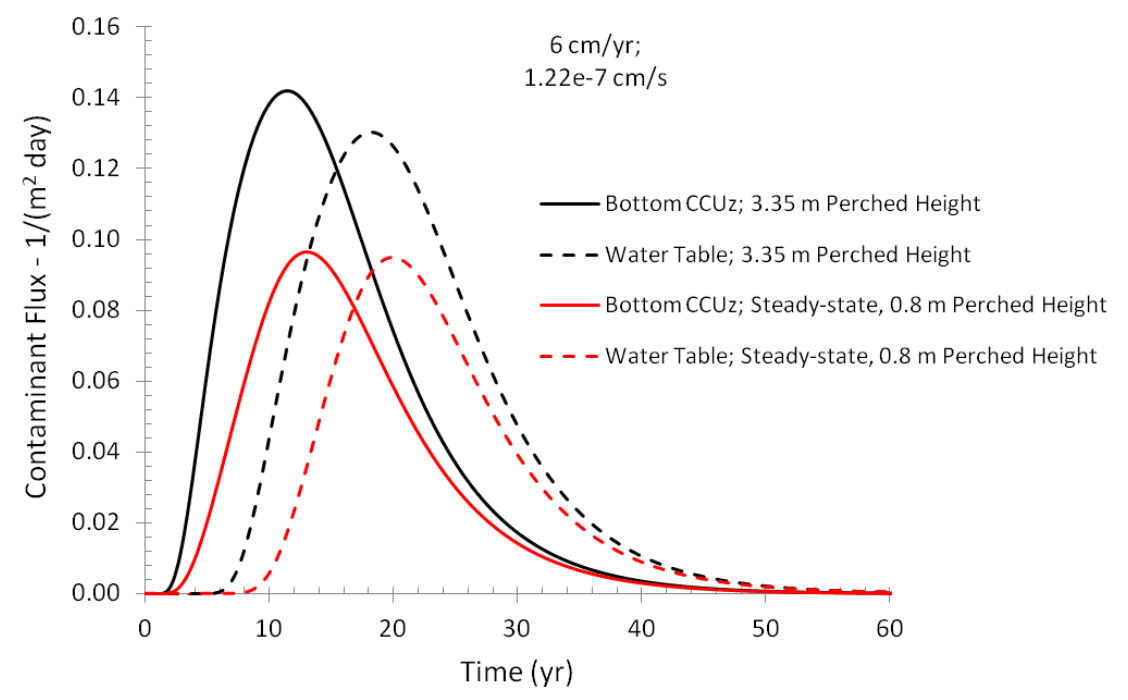

Figure 14. Simulated transient contaminant flux out the bottom of the perching layer (bottom CCUz) and to groundwater (water table) with an imposed initial perched-water height $\left(L_{p}\right)$ of $3.36 \mathrm{~m}$ and at the steady-state perched-water height $(\sim 0.8 \mathrm{~m})$ for a perching-layer-saturated hydraulic conductivity $\left(K_{\text {sat,c }}\right)$ of $1.22 \times 10^{-7} \mathrm{~cm} / \mathrm{s}$ and a recharge rate $(R)$ of $6 \mathrm{~cm} / \mathrm{yr}$.

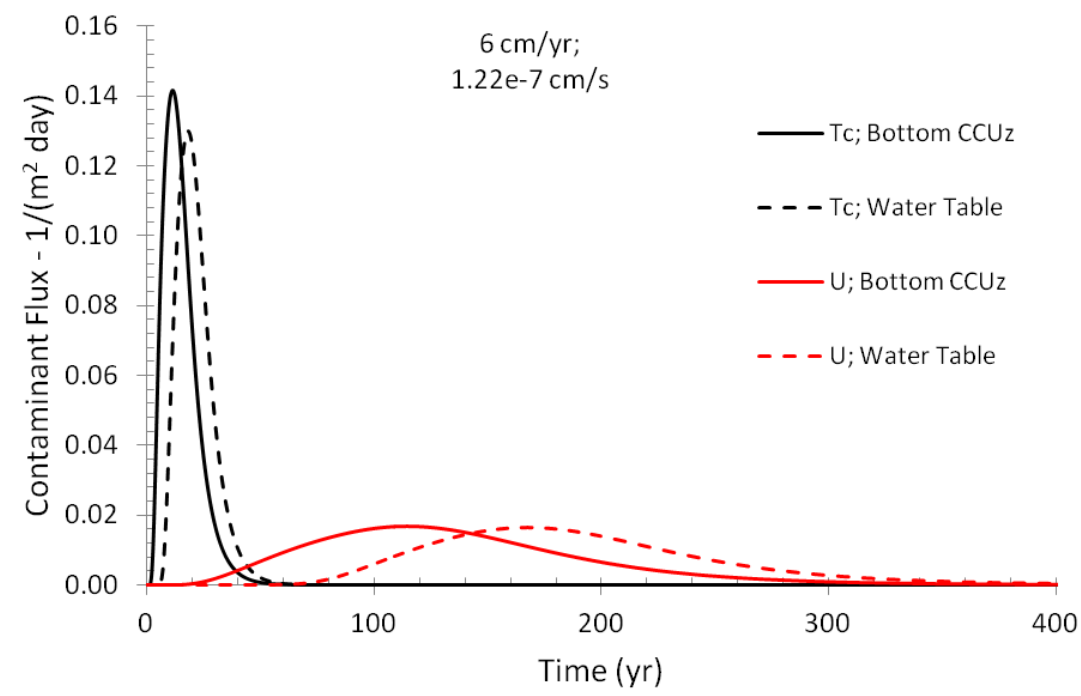

Figure 15. Simulated transient contaminant flux out the bottom of the perching layer (bottom CCUz) and to groundwater (water table) with an imposed initial perched-water height $\left(L_{p}\right)$ of $3.36 \mathrm{~m}$, a perching-layer-saturated hydraulic conductivity $\left(K_{\text {sat }, c}\right)$ of $1.22 \times 10^{-7} \mathrm{~cm} / \mathrm{s}$, and a recharge rate $(R)$ of $6 \mathrm{~cm} / \mathrm{yr}$. Contaminant fluxes for technetium-99 (Tc) (non-sorbing) and uranium (U) (sorbing) are shown. 


\subsection{Conclusions}

A quantitative analysis of the perched water system in the B, BX, and BY Tank Farms area was conducted to support evaluation of 1) contaminant flux from the perched water to groundwater over time and 2) the impact of perched-water removal. The approach used a one-dimensional (vertical) analysis, which is appropriate to evaluate behavior of the perched-water system based on the vertical driving forces and transport pathways and large areal extent of the perched system. However, this approach does not consider lateral variations in subsurface properties or flow. Although the conceptual model for generating the current perched-water system from surface discharges includes lateral water flow conditions in the subsurface, future movement of perched water to the groundwater is expected to be vertical. Thus, the one-dimensional model provides a tool to evaluate this movement and how it is controlled by the properties of the perching layer and the hydraulic driving forces. Variations in recharge are used in the model as the overall driving force for water migration through the vadose zone. Although the recharge is modeled as a vertical driving force and water moves into the perched system from the top of the model, this configuration would also be representative of the same quantity of water moving into the perched system laterally, with perched-water conditions and flow downward out of the perching zone controlled by vertical flow through the perching layer.

The presence of perched water enables use of a pumping system for removal of contaminant mass from the subsurface to decrease the total contaminant mass that would eventually move into the groundwater. Under most of the tested scenarios, the perched water is a transient condition, although continuation of current disturbed-surface recharge conditions for the B, BX, and BY Tank Farms area may maintain the perched-water zone to some extent, even as the impacts of historical waste and water discharges dissipate. For transient perched-water conditions, especially when coupled with a decreased recharge rate (and/or dissipation of previous waste and water discharges), declining perched-water height will render removal of perched water more difficult with time. As such, near-term actions to remove perched water will be more effective. Removal of perched water by pumping would hasten the transition to conditions in which the flux of water (and associated contaminants) through the vadose zone to the groundwater approaches the recharge rate. Reducing the recharge rate would further decrease the flux of water (and associated contaminants) to the groundwater, thereby impacting the long-term rate of contaminant movement to the groundwater. Reduction of recharge is also important to consider because contaminants are present in other parts of the vadose zone, not only within the current perched water. Thus, a coupled effort of perched-water removal and recharge rate reduction would cause the most significant decrease in contaminant flux to the groundwater. In addition, other methods to decrease contaminant flux through the vadose zone (e.g., in situ treatment) could be combined with these approaches to further decrease impact to groundwater, if needed.

Steady-state scoping calculations were used to evaluate a wide range of recharge and perching-layer hydraulic conductivity conditions with respect to creating perched water. These results helped bound the

range of conditions that are consistent with the observed perched water. Numerical simulations provided both steady-state and transient system estimates of water and contaminant behavior and were used to further refine the range of conditions consistent with current observations of perched water height. In addition, the simulations provided estimates of future water and contaminant flux to groundwater for those conditions. The modeling analyses were conducted and compared to the currently available perched-water data, which represent a relatively short timeframe, to bound the range of future perchedwater behavior. Thus, continued observation of the perched-water height over time and the response to 
continued pumping operations will be useful to refine and improve the estimates of perched-water conditions and associated predictions of flux to groundwater.

Key conclusions from the study are provided below.

- A limited number of perched-water system configurations are consistent with water flow physics within the vadose zone. For simulation results to be consistent with the estimated recent and current recharge for disturbed surface conditions on the order of $6 \mathrm{~cm} / \mathrm{yr}$ and the observed relatively stable perched-water height during a year of pumping, the perching-layer hydraulic conductivity is likely to be less than the base case value and closer to $1 \times 10^{-7} \mathrm{~cm} / \mathrm{s}$.

- The following potential perched-water behaviors are consistent with the results of this study.

- With an assumption of a current $6-\mathrm{cm} / \mathrm{yr}$ recharge rate, the saturated hydraulic conductivity of the perching layer would need to be low $\left(\sim 1 \times 10^{-7} \mathrm{~cm} / \mathrm{s}\right)$ and the perched water table would be expected to slowly decline over a period of about 20 years to reach a steady-state condition where perched water is still present $(\sim 0.8 \mathrm{~m})$ but with a water height less than that observed today $(\sim 3.36 \mathrm{~m})$. Water flux from the perched water to the groundwater during the decline in the perched water table would be in the range of $10 \mathrm{~cm} / \mathrm{yr}$ (current) and decline to the steady-state value of $6 \mathrm{~cm} / \mathrm{yr}$. Removal of perched water would hasten reaching this steady-state water flux and associated contaminant flux and decrease the total contaminant mass that would eventually move into the groundwater.

- If the current recharge rate is about $12 \mathrm{~cm} / \mathrm{yr}$ (due to drainage of water present above the perched system and continued high recharge at the surface), then the perched-water height would remain steady as long as this recharge is maintained. During this time, water flux from the perched water to the groundwater would also be $12 \mathrm{~cm} / \mathrm{yr}$ and decline only when the recharge rate is decreased. For a condition in which this recharge rate remained constant over time, if some perched water were removed, the perched-water height would be expected to rebound to current conditions and the water flux to groundwater remain relatively unaffected. However, perched-water removal would decrease the total contaminant mass that will eventually move into the groundwater.

- For a recharge rate of $6 \mathrm{~cm} / \mathrm{yr}$, a perching-layer-saturated hydraulic conductivity of about $6 \times 10^{-8} \mathrm{~cm} / \mathrm{s}$ would also produce a relatively stable perched-water height of $3.36 \mathrm{~m}$. Under this condition, water flux to groundwater would remain constant at $6 \mathrm{~cm} / \mathrm{yr}$ and decline only when the recharge rate is decreased. For a condition in which this recharge rate remained constant over time, if some perched water were removed, the perched-water height would be expected to rebound to current conditions and the water flux to groundwater remain relatively unaffected. However, perched-water removal would decrease the total contaminant mass that will eventually move into the groundwater.

- If the recharge rate is decreased from $6 \mathrm{~cm} / \mathrm{yr}$ to $0.35 \mathrm{~cm} / \mathrm{yr}$ (e.g., through installation of a surface barrier or other means), the perched water table would decline and reach unsaturated conditions. During this time, water flux from the perched water to the groundwater would decline from about $10 \mathrm{~cm} / \mathrm{yr}$ to $0.35 \mathrm{~cm} / \mathrm{yr}$ and contaminant flux to the groundwater would be reduced and delayed significantly. Removal of perched water via pumping would hasten reaching this steady-state water flux and associated contaminant flux and decrease the total contaminant mass that will eventually move into the groundwater. 
- Contaminant flux is delayed compared to water flux due to transport through the CCUg and, when applicable, by sorption. If current observations of groundwater contaminants are due to flux from the perched-water system, then concentrations would be expected to continue rising or, at minimum, be stable over the next decade (based on 6-cm/yr recharge and $1.22 \times 10^{-7} \mathrm{~cm} / \mathrm{s} K_{\text {sat,c }}$ results). Interpretation of current groundwater contaminant concentrations should consider the potential effects of alternative transport pathways (natural or via poorly sealed well casings) in addition to the transport from the perched-water system.

- Long-term behavior of contaminant flux to the groundwater is related to the contaminated perched water, as simulated in this study, and the mobile contaminants present in the vadose zone above the perched water zone. Thus, short-term perched-water removal provides benefits primarily in decreasing the total contaminant mass that will eventually move into the groundwater and hastening transition of the vadose water flux to being controlled by the recharge rate. In this case, coupling perched-water removal with reduction of the recharge rate (e.g., a surface barrier) and/or other methods to decrease contaminant flux through the vadose zone (e.g., in situ treatment) could be considered to provide a larger reduction in the contaminant flux to groundwater (and associated groundwater contaminant concentrations) than can be achieved by perched-water removal alone.

This study was intended to provide a quantitative context for interpreting the observed perched-water system and ramifications for groundwater impact based on a hydraulic analysis of the vadose zone system. The concentration profile and extent of the groundwater plume produced by contaminant flux from the vadose zone is related to three-dimensional aspects of the subsurface system. Use of a coupled analysis for the vadose zone source and the groundwater transport system could be applied to evaluate the nature and extent of the groundwater plume over time and could incorporate aspects of the current study in defining the vadose zone source term.

\subsection{References}

Adam ML, SD Comfort, and DD Snow. 2004. "Remediating RDX-contaminated Ground Water with Permanganate: Laboratory Investigations for the Pantex Perched Aquifer." Journal of Environmental Quality 33:2165-2173.

Birdsell KH, BD Newman, DE Broxton, and BA Robinson. 2004. "Conceptual Models of Vadose Zone Flow and Transport Beneath the Pajarito Plateau, Los Alamos, New Mexico." Vadose Zone Journal 4:620-636.

Carroll KC, M Oostrom, MJ Truex, VJ Rohay, and ML Brusseau. 2012. "Assessing Performance and Closure for Soil Vapor Extraction: Integrating Vapor Discharge and Impact to Groundwater Quality." Journal of Contaminant Hydrology 128(1-4):71-82.

Duke CL, RC Roback, PW Reimus, RW Bowman, TL McLing, KE Baker, and L Hull. 2007. "Elucidation of Flow and Transport Processes in a Variably Saturated System of Interlayered Sediment and Fractured Rock Using Tracer Tests.” Vadose Zone Journal 6:855-867. 
Fayer MJ, AL Ward, and VL Freedman. 2010. Technical Basis for Evaluating Surface Barriers to Protect Groundwater from Deep Vadose Zone Contamination. PNNL-18661, Pacific Northwest National Laboratory, Richland, Washington.

Flint AL and KM Ellett. 2004. "The Role of the Unsaturated Zone in Artificial Recharge at San Gorgonio Pass, CA.” Vadose Zone Journal 3:763-774.

Flint AL, KM Ellett, AH Christensen, and P Martin. 2012. "Modeling a Thick Unsaturated Zone at San Gorgonio Pass, CA: Lessons Learned after Five Years of Artificial Recharge." Vadose Zone Journal doi:10.2136/vzj2012.0043.

Freeze RA and JA Cherry. 1979. Groundwater. Prentice-Hall, Englewood Cliffs, New Jersey.

Kellin CJ, L Barbour, and C Qualizza. 2009. "Fracture-dominated Subsurface Flow and Transport in a Sloping Reclamation Cover." Vadose Zone Journal 8:96-107.

Kwicklis E, M Witkowski, KH Birdsell, BD Newman, and D Walther. 2005. "Development of an Infiltration Map for the Los Alamos Area, New Mexico." Vadose Zone Journal 4:672-693.

Lindenmeier CW, RJ Serne, BN Bjornstad, GW Gee, HT Schaef, DC Lanigan, MJ Lindberg, RE Clayton, VL Legore, IV Kutnyakov, SR Baum, KN Geiszler, CF Brown, MM Valenta, TS Vickerman, and LJ Royack. 2008. Characterization of Vadose Zone Sediment: RCRA Borehole 299-E33-338 Located Near the B-BX-BY Waste Management Area. PNNL-14121, Rev. 1, Pacific Northwest National Laboratory, Richland, Washington.

Nimmo JR, KS Perkins, PA Rose, JP Rousseau, BR Orr, BV Twining, and SR Anderson. 2002. "Kilometer-scale Rapid Transport of Naphthalene Sulfonate Tracer in the Unsaturated Zone at the Idaho National Engineering and Environmental Laboratory." Vadose Zone Journal 1:89-101.

Nimmo JR, JP Rousseau, KS Perkins, KG Stollenwerk, PD Blunn, RC Bartholomay, and LL Knobel. 2004. "Hydraulic and Geochemical Framework of the Idaho National Engineering and Environmental Laboratory Vadose Zone." Vadose Zone Journal 3:6-34.

Oostrom M, MJ Truex, GD Tartakovsky, and TW Wietsma. 2010. “Three-Dimensional Simulation of Volatile Organic Compound Mass Flux from the Vadose Zone to Groundwater." Groundwater Monitoring \& Remediation 30(3):45-56. doi:10.1111/j1745-6592.2010.001285.x.

Robinson BA, DE Broxton, and DT Vaniman. 2005. "Observations and Modeling of Deep Perched Water Beneath the Pajarito Plateau." Vadose Zone Journal 4:637-652.

Robinson BA, JE Houseworth, and S Chu. 2011. "Radionuclide Transport in the Unsaturated Zone at Yucca Mountain, NV.” Vadose Zone Journal 11(4). doi:10.2136/vzj2011.0133.

Serne RJ, GV Last, GW Gee, HT Schaef, DC Lanigan, CW Lindenmeier, MJ Lindberg, RE Clayton, VL Legore, RD Orr, IV Kutnyakov, SR Baum, KN Geiszler, CF Brown, MM Valenta, and TS Vickerman. 2008. Characterization of Vadose Zone Sediment: Borehole 299-E33-45 Near BX-102 in the B-BX-BY Waste Management Area. PNNL-14083, Rev. 1, Pacific Northwest National Laboratory, Richland, Washington. 
Serne R, B Bjornstad, J Keller, P Thorne, D Lanigan, J Christensen, and G Thomas. 2010. Conceptual Models for Migration of Key Groundwater Contaminants Through the Vadose Zone and Into the Upper Unconfined Aquifer Below the B-Complex. PNNL-19277, Pacific Northwest National Laboratory, Richland, Washington.

Truex MJ and KC Carroll. 2013. Remedy Evaluation Framework for Inorganic, Non-Volatile Contaminants in the Vadose Zone. PNNL-21815, Pacific Northwest National Laboratory, Richland, Washington.

Uchida T, Y Asano, T Mizuyama, and J McDonnell. 2004. "Role of Upslope Soil Pore Pressure on Lateral Subsurface Storm Flow Dynamics.” Water Resources Research 40:W12401. doi:10.1029/ 2003WR002139.

van Genuchten MTh. 1980. "A Closed Form Equation for Predicting the Hydraulic Conductivity of Unsaturated Soils.” Soil Science Society of America Journal 44(5):892-898.

Wang L, JQ Wu, LC Hull, and AL Schafer. 2010. "Modeling Reactive Transport of Strontium-90 in a Heterogeneous Variably Saturated Subsurface.” Vadose Zone Journal 9:670-685.

White MD and M Oostrom. 2006. STOMP - Subsurface Transport Over Multiple Phases, Version $4.0-$ User's Guide. PNNL-15782, Pacific Northwest National Laboratory, Richland, Washington.

Williams BA, VJ Rohay, and MH Doornbos. 2012. Path Forward Recommendations Report for the Uranium Contamination in the B Area. SGW-53604, Revision 0, CH2M HILL Plateau Remediation Company, Richland, Washington.

Wu YS, AC Ritcey, and GS Bodvarsson. 1999. “A Modeling Study of Perched Water Phenomena in the Unsaturated Zone at Yucca Mountain.” Journal of Contaminant Hydrology 38(1-3):157-184.

Wu YS, G Lu, K Zhang, and GS Bodvarsson. 2004. “A Mountain-scale Model for Characterizing Unsaturated Flow and Transport in Fractured Tuffs of Yucca Mountain." Vadose Zone Journal 3:796-805.

Zhong L, M Oostrom, TW Wietsma, and MA Covert. 2008. "Enhanced Remedial Amendment Delivery through Fluid Viscosity Modifications: Experiments and Numerical Simulations." Journal of Contaminant Hydrology 101(1-4):29-41. doi:10.1016/j.jconhyd.2008.07.007. 

PNNL-22499

RPT-DVZ-AFRI-013

\section{Distribution}

No. of

$\underline{\text { Copies }}$

ONSITE

DOE, Richland Operations Office

JG Morse

A5-11

CH2M HILL Plateau Remediation

Company

GB Chronister

R3-50
No. of

$\underline{\text { Copies }}$

3 Pacific Northwest National Laboratory

KC Carroll

PDF

M Oostrom

K9-33

MJ Truex

K6-96

DM Wellman

Distr.1 




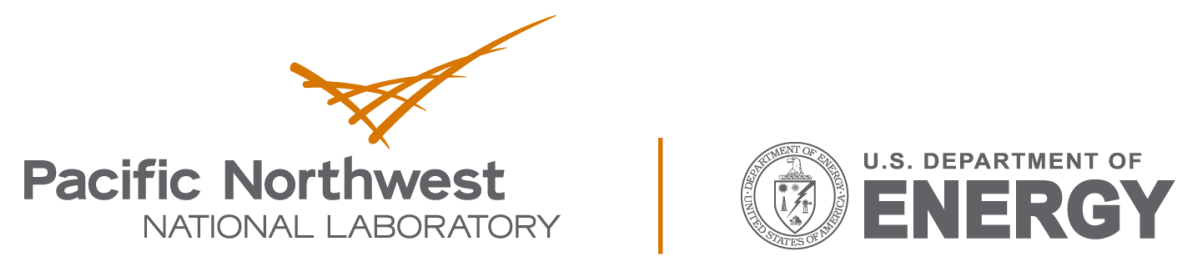

Proudly Operated by Battelle Since 1965

902 Battelle Boulevard

P.O. Box 999

Richland, WA 99352

1-888-375-PNNL (7665)

www.pnnl.gov 